\title{
Mitochondrial Transplantation: Is It a Feasible Therapy to Prevent the Cardiorenal Side Effects of Cisplatin?
}

\author{
Isabel Amador-Martínez ${ }^{1,2}$, Estefani Yaquelin Hernández-Cruz ${ }^{1,2} \mathbb{D}$, Alexis Paulina Jiménez-Uribe ${ }^{1(D)}$, \\ Laura Gabriela Sánchez-Lozada ${ }^{3}$, Omar Emiliano Aparicio-Trejo ${ }^{3}$, Edilia Tapia ${ }^{3}$, Jonatan Barrera-Chimal ${ }^{4,5}$ (D) \\ and José Pedraza-Chaverri ${ }^{1, * \mathbb{D}}$
}

Citation: Amador-Martínez, I.; Hernández-Cruz, E.Y.; Jiménez-Uribe, A.P.; Sánchez-Lozada, L.G.;

Aparicio-Trejo, O.E.; Tapia, E.; Barrera-Chimal, J.; Pedraza-Chaverri,

J. Mitochondrial Transplantation: Is It a Feasible Therapy to Prevent the Cardiorenal Side Effects of Cisplatin? Future Pharmacol. 2021, 1, 3-26. https://doi.org/10.3390/ futurepharmacol1010002

Academic Editor: Fabrizio Schifano

Received: 28 July 2021

Accepted: 8 September 2021

Published: 15 September 2021

Publisher's Note: MDPI stays neutral with regard to jurisdictional claims in published maps and institutional affiliations.

Copyright: (c) 2021 by the authors. Licensee MDPI, Basel, Switzerland. This article is an open access article distributed under the terms and conditions of the Creative Commons Attribution (CC BY) license (https:// creativecommons.org/licenses/by/ $4.0 /)$.
1 Department of Biology, Faculty of Chemistry, National Autonomous University of Mexico (UNAM), Mexico City 04510, Mexico; amador_i@ciencias.unam.mx (I.A.-M.); estefani.hernandez@quimica.unam.mx (E.Y.H.-C.); jimenez.uribe.ap@comunidad.unam.mx (A.P.J.-U.)

2 Posgrado en Ciencias Biológicas, Universidad Nacional Autónoma de México, Ciudad Universitaria, Mexico City 04510, Mexico

3 Department of Cardio-Renal Physiopathology, National Institute of Cardiology "Ignacio Chávez", Mexico City 14080, Mexico; laura.sanchez@cardiologia.org.mx (L.G.S.-L.); svarta02@comunidad.unam.mx (O.E.A.-T.); edilia.tapia@cardiologia.org.mx (E.T.)

4 Instituto de Investigaciones Biomédicas, Universidad Nacional Autónoma de México, Ciudad Universitaria, Mexico City 04510, Mexico; jbarrera@iibiomedicas.unam.mx

5 Laboratorio de Fisiología Cardiovascular y Trasplante Renal, Unidad de Investigación UNAM-INC, Instituto Nacional de Cardiología Ignacio Chávez, Mexico City 14080, Mexico

* Correspondence: pedraza@unam.mx

Abstract: Mitochondrial transplantation (MT) is a new experimental approach that has demonstrated positive results reverting mitochondrial alterations in cardiac and kidney dysfunction mainly mediated by oxidative stress. On the other hand, cisplatin is an effective and widely used antineoplastic drug in treating several cancers; however, cisplatin has notorious side effects in different organs, such as the heart, kidneys, liver, and brain; the kidney being one of the most affected. The genitourinary system is the principal excretion pathway of cisplatin, since it is removed from the blood primarily by glomerular filtration and tubular secretion, and it may cause a sudden reduction in the renal function (acute kidney injury "AKI"), in part, by inducing mitochondrial dysfunction and the consequent oxidative stress in the tubular segment. In addition, AKI may associate with cardiac alterations, as occurs in acute cardiorenal syndrome. Due to the high prevalence of renal and cardiac side effects produced by cisplatin, here we discuss the possible use of MT as a novel therapy that could protect tissues by alleviating mitochondrial dysfunction and reducing reactive oxygen species (ROS) production.

Keywords: mitochondrial transplantation; cisplatin; acute kidney injury; heart failure; oxidative stress; mitochondrial dysfunction

\section{Acute Kidney Injury}

Acute kidney injury (AKI) is a clinical syndrome, defined by an abrupt decrease in glomerular filtration, that encompasses several clinical scenarios, aetiologies, comorbidities, drug exposures and severities of renal dysfunction [1,2]. Drugs are the third to the fifth leading cause of AKI in the intensive care unit [3,4]. Additionally, drug induced AKI accounts for $20-30 \%$ of critically ill patients [3] and may play a causative role in as many as $25 \%$ of all cases considered a severe public health problem [5,6]. Approximately $20 \%$ of the cases require renal replacement therapy [3], which is related to increased mortality, and this reaches rates of over $60 \%$ in developing countries [7].

Nephrotoxicity is caused, directly or indirectly, when a drug, chemical, or toxin causes damage to kidney function or structure [7]. Acute tubular necrosis is the most common intrinsic kidney injury, mainly caused by the basolateral and apical efflux of several drugs, 
such as antimicrobials, antivirals, chemotherapeutics, immunosuppressants, radiocontrast agents and others [8,9].

\subsection{Platinum Based Drugs in Cancer}

Between all nephrotoxic drugs, chemotherapeutic agents remain a significant complication limiting the efficacy of treatment. Platinum based drugs (PBDs) are widely used antineoplastic drugs, inducing apoptosis of cancer cells and modulating immune responses [10]. PBDs mainly include cisplatin, carboplatin, oxaliplatin, nedaplatin, lobaplatin, hepatplatin, and miriplatin $[10,11]$. Currently, cisplatin, carboplatin, and oxaliplatin are still extensively applied in the treatment of several cancers [10], even considering the best treatment options [12-14]. Cisplatin and carboplatin are commonly used for ovarian, lung, and head and neck cancers $[15,16]$. Carboplatin based regimens are frequently recommended for women with platinum sensitive recurrent ovarian cancer, and oxaliplatin was approved for enlarged spectrum or decreased toxicity and is commonly used in colorectal cancer [15]. Although the three PBDs used in clinics cause nephrotoxicity, cisplatin is the most toxic, followed by the others [17].

\subsection{Cisplatin Induced AKI}

Recent reports have shown that AKI occurs in $21-31.5 \%$ of patients receiving cisplatincontaining chemotherapy $[18,19]$, but still today, cisplatin induced AKI is not well defined in humans [20]. Cisplatin nephrotoxicity depends upon the dose and frequency of drug administration and the concomitant use of other nephrotoxic agents, such as aminoglycosides, nonsteroidal anti-inflammatory drugs, or iodinated contrast media $[9,21]$. Comorbidities, such as diabetes mellitus, chronic kidney disease (CKD), heart failure, anemia, sepsis, and major surgeries, also increase the risk of developing AKI [20,22], and susceptibility rises even more with age (>65 years) [1]. Patients generally experience cisplatin nephrotoxicity after 10 days of administration and show a reduced glomerular filtration rate, higher serum creatinine, and reduced serum and potassium levels [22]. The persistent damage produced by AKI can lead to CKD, end stage renal disease, and physiological disturbances $[1,2,23]$. Besides, AKI increases mortality and tumor relapse, or secondary tumors development, due to treatment abandonment [24].

Cisplatin passes to glomerular filtration and is secreted by the proximal tubular cells (PTCs), mainly affecting this tubular secretion $[22,25,26]$. Due to the reabsorption and secretion functions of the proximal tubule, there is a high energy demand; hence, a high content of mitochondria [27]. Cisplatin induced acute tubular necrosis is mainly caused by intracellular accumulation, and may produce several kidney disturbances, such as renal failure, renal tubular acidosis, hypomagnesemia, and salt-wasting, principally by tubular injury [21,26]. Although the most common prevention therapies include hydration, forced diuresis (mannitol), hemodialysis, and the reduction/discontinuing doses of cisplatin, patients are at a high risk of developing progressive renal impairment $[21,28]$.

\subsection{Cisplatin-Induced AKI and the Cardiorenal Association}

Due to the crosstalk between the heart and kidney, one organ dysfunction or failure results in maladaptive changes in the other [23]. In clinical practice, this association has been called cardiorenal syndrome (CRS) [29] (Figure 1). CRS classification is denoted by the principal organ dysfunction by temporal sequence and the relative acuity of each illness [30,31]. AKI may lead to diastolic dysfunction within $72 \mathrm{~h}$, but it can persist up to 12 months after AKI, suggesting that systemic effects during the initial AKI episode are likely contributors to long term cardiovascular disease [1,32]. AKI produces systemic effects that increase inflammation, cardiac dysfunction, and metabolic disorders, such as reducing adenosine $5^{\prime}$-triphosphate $(\mathrm{ATP})$ formation in the heart [32]. Cardiotoxic manifestations also include heart failure, angina, acute myocardial infarction, thromboembolic events, autonomic cardiovascular dysfunction, hypertension and hypotension, and severe congestive cardiomyopathy [33]. 


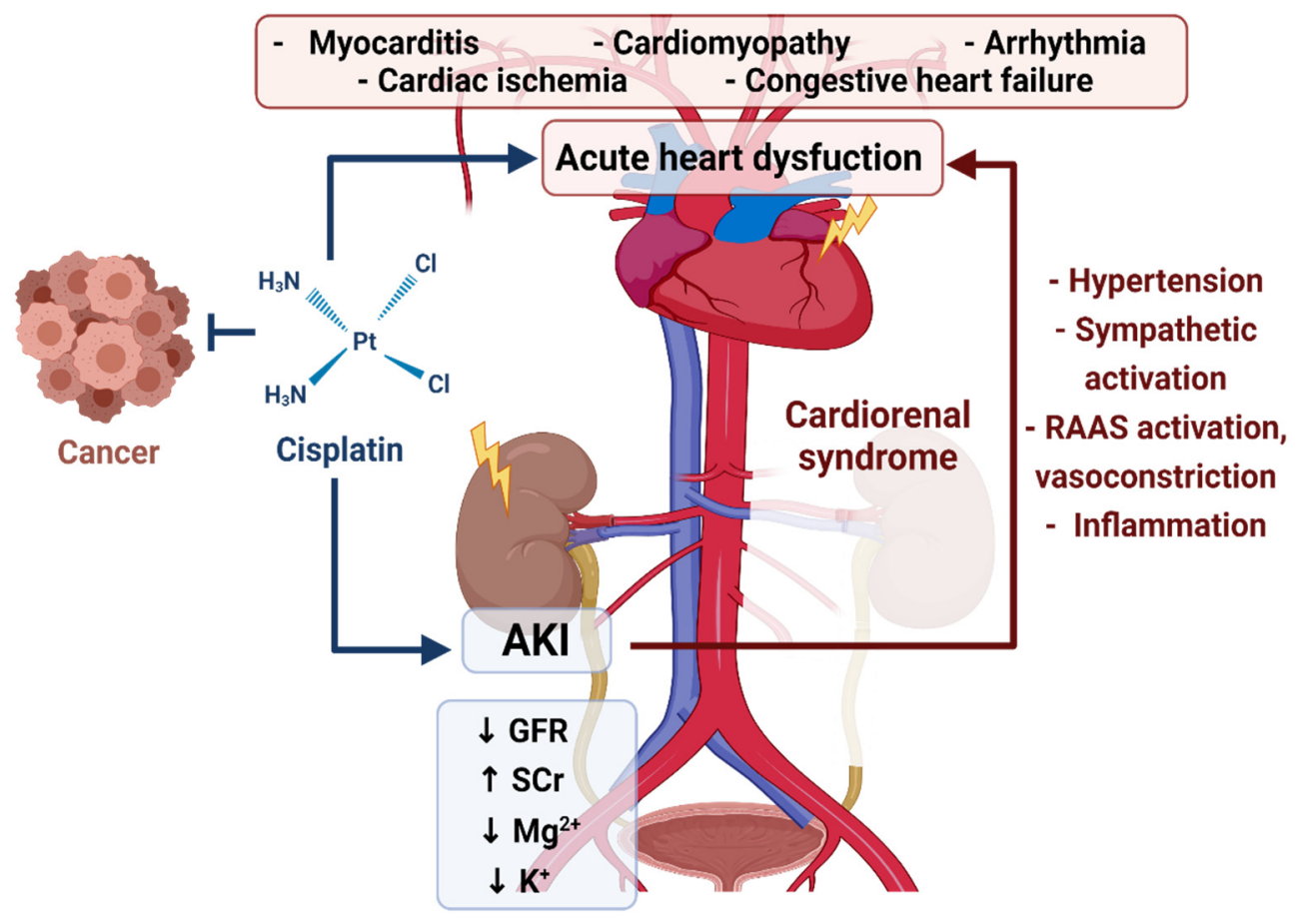

Figure 1. Cisplatin induced cardiorenal damage. Cisplatin is an antineoplastic agent used to treat different cancers; however, it produces side effects such as nephrotoxicity and cardiotoxicity. Cisplatin causes decreased glomerular filtration rate (GFR), increased serum creatinine ( $\mathrm{SCr}$ ), reduced serum magnesium $\left(\mathrm{Mg}^{2+}\right)$ and potassium $\left(\mathrm{K}^{+}\right)$levels, leading to acute kidney injury (AKI). The persistence of AKI produces systemic effects that increase inflammation, activate the renin-angiotensinaldosterone system (RAAS), sympathetic activation and cause hypertension leading to acute heart dysfunction. AKI also causes other cardiovascular alterations, such as myocarditis, congestive heart failure, cardiomyopathy, cardiac ischemia, and arrhythmias. Created with BioRender.com (with copyright permission from BioRender.com).

Cisplatin induced AKI triggers a degenerative process of medium thickness vessel walls, thus causing the reduction of the vascular lumen in the long term, which associates with the development of hypertension [34,35]. Cardiovascular morbidity and mortality due to long term dysfunction include the interaction of different mechanisms, such as reninangiotensin-aldosterone system activation, volume overload, and inflammation [2,32,36]. A recent observational study concluded that patients who recovered from testicular cancer three decades after the treatment did not show an overt or subclinical reduction in systolic function. In the long term, cardiovascular effects were related to metabolic dysfunction and diastolic function [37]. Venous and arterial thrombosis, arrhythmogenic electrolyte alterations, and volume overload have been more related to renal toxicity and the large volume of fluid typically administered during cisplatin treatment [38].

Not all observational studies support cisplatin chemotherapy as etiologically related to a statistical increase in late cardiovascular morbidity and mortality, but more studies to elucidate the potential pathophysiologic mechanisms occurring during treatment would be more exact to support downstream cardiac morbidity and mortality [38,39]. Animal models under cisplatin therapy develop dampened heart function, impaired cardiac excitationcontraction coupling, damaged myocardial contractility, bradycardia, reduced blood pressure, and degenerative changes such as vascular congestion and fibrosis $[34,40,41]$ (see Table 1). 
Table 1. Cisplatin treatment leads to cardiovascular disturbances.

\begin{tabular}{|c|c|c|c|c|}
\hline Model & $\begin{array}{l}\text { Cisplatin Dose/Time of } \\
\text { Administration }\end{array}$ & Heart Alterations & Other Alterations & Reference \\
\hline $\begin{array}{c}\text { Female } 8 \text {-week-old Wistar } \\
\text { albino rats } \\
190-250 \mathrm{~g}\end{array}$ & $\begin{array}{c}\text { Single doses of } \\
5 \mathrm{mg} / \mathrm{kg} / \text { week, (i.p), two } \\
\text { times as once a week } \\
19 \text { days of study }\end{array}$ & $\begin{array}{c}\uparrow \text { MDA } \\
\downarrow \text { SOD, CAT } \\
\uparrow \text { Proinflammatory cytokines: IL- } 1 \beta, \\
\text { IL-6, and TNF- } \alpha \text { in the cardiac tissue. } \\
\text { Muscle fiber damage, cytoplasmic } \\
\text { vacuolization, hemorrhage, and } \\
\text { interstitial edema. }\end{array}$ & None & Bahadir et al. [42] \\
\hline $\begin{array}{l}\text { Male Wistar rats } \\
\text { 200-250 g }\end{array}$ & $\begin{array}{c}4 \mathrm{mg} / \mathrm{kg}(\mathrm{i} . \mathrm{p}), \\
4 \text { repetitions: day } 1,5,9, \\
\text { and } 13 \text { (Total }=16 \mathrm{mg} / \mathrm{kg}) \\
14 \text { days of study }\end{array}$ & $\begin{array}{c}\uparrow \text { CK-MB, cTnI } \\
\text { Disarrayed cardiac muscle fibers } \\
\text { arrangement, severe interstitial } \\
\text { edema, vacuolar degeneration of } \\
\text { muscle cells, and congestion of blood } \\
\text { vessels. } \\
\uparrow \text { LVSP } \\
\downarrow \text { LVEDP } \\
\uparrow \text { Cardiac MDA } \\
\downarrow \text { SOD, CAT, GHS, and GPx } \\
\uparrow \text { Apoptosis } \\
\uparrow \text { Caspase-3 } \uparrow \text { PARP }\end{array}$ & $\begin{array}{c} \\
\text { Weight loss } \\
\text { Hypotension } \\
\uparrow \text { Nrf-2 } \\
\uparrow \text { keap1, NQO1, and } \\
\text { HO-1 }\end{array}$ & Y. Cui et al. [41] \\
\hline $\begin{array}{l}\text { Male albino rats } \\
180-220 \mathrm{~g}\end{array}$ & $\begin{array}{c}\text { Repeated doses of } 2 \\
\mathrm{mg} / \mathrm{mg} / \mathrm{kg} / \text { day (i.p) for } \\
1 \text { week } \\
12 \text { days of study }\end{array}$ & $\begin{array}{c}\text { Disturbed architecture of cardiac } \\
\text { muscle and separated muscle fibers } \\
\text { and extravasation of RBCs. } \\
\text { Degenerated and disrupted cardiac } \\
\text { muscle fibers. Deposition of } \\
\text { collagenous fibers and cardiac } \\
\text { muscle fibers with irregular } \\
\text { shrunken nuclei, swollen and } \\
\text { disrupted mitochondria, and dilated } \\
\text { sarcoplasmic reticulum. } \\
\uparrow \text { CK-MB, LDH }\end{array}$ & $\begin{array}{l}\uparrow \mathrm{p} 53 \text { in the } \\
\text { cardiomyocytes } \\
\text { nuclei. } \\
\uparrow \text { TNF- } \alpha\end{array}$ & $\begin{array}{c}\text { El-Hawwary \& Omar. } \\
{[34]}\end{array}$ \\
\hline $\begin{array}{l}\text { Male 5-week-old Balb/c } \\
\text { mice } \\
20-30 \mathrm{~g}\end{array}$ & $\begin{array}{c}\text { Single-dose of } 7 \mathrm{mg} / \mathrm{kg} \text {, } \\
\text { (i.p) } \\
31 \text { days of study }\end{array}$ & $\begin{array}{c}\uparrow \text { Troponin } 1, \mathrm{CPK}, \mathrm{CK}-\mathrm{MB} \\
\uparrow \mathrm{MDA} \\
\downarrow \text { GPx, SOD, catalase } \\
\uparrow \mathrm{NO} \\
\text { Disruption of cardiac muscle fibers, } \\
\text { loss of striations, pyknotic nuclei, } \\
\text { interrupted cardiac muscle fibers of } \\
\text { the myocardium. }\end{array}$ & $\begin{array}{l}\downarrow \text { Body weight } \\
\downarrow \text { Heart weight } \\
\downarrow \text { Heart index }\end{array}$ & $\begin{array}{l}\text { M.A Ibrahim et al. } \\
\text { [40] }\end{array}$ \\
\hline $\begin{array}{l}\text { Male Wistar rats } \\
180-200 \mathrm{~g}\end{array}$ & $\begin{array}{c}\text { Single-dose of } 10 \mathrm{mg} / \mathrm{kg} \text {, } \\
\text { (i.p) } \\
5 \text { days of study }\end{array}$ & $\begin{array}{c}\text { ECG changes (elongation of QTc } \\
\text { duration and increased ST and T } \\
\text { wave amplitude). } \\
\uparrow \text { Heart rate } \\
\uparrow \text { Troponin I, LDH, CK-MB } \\
\downarrow \text { GSH, SOD } \\
\uparrow \text { Caspase-12, Bax } \\
\downarrow \text { Bcl-2 } \\
\uparrow \text { Bax / Bcl- } 2 \text { ratio in heart }\end{array}$ & $\begin{array}{l}\uparrow \text { GRP78 } \\
\uparrow \text { Calpain-1 } \\
\uparrow \text { aCASP3 }\end{array}$ & Saleh et al. [43] \\
\hline
\end{tabular}

Abbreviations: aCASP3: activated caspase 3, Bax: BCL2-Associated X Protein, Bcl-2: B-cell lymphoma 2, CAT: catalase, CK-MB: creatine kinase isoenzyme-MB, CPK: creatine phosphokinase, cTnI: cardiac troponin 1, ECG: electrocardiogram, GPx: glutathione peroxidase, GRP78: 78-kDa glucose-regulated protein, GSH: glutathione, HO-1: heme oxygenase-1, IL: interleukin, i.p: intraperitoneal, LDH: lactate dehydrogenase, LVEDP: left ventricular end-diastolic pressure, LVSP: left ventricular systolic pressure, MDA: malondialdehyde, NO: nitric oxide, NQO1: quinone oxidoreductase, Nrf-2: nuclear factor erythroid 2-related factor 2, PARP: poly (ADP-ribose) polymerase, tumor protein: p53 RBCs: red blood cells, SOD: superoxide dismutase, TNF- $\alpha$ : tumor necrosis factor-alpha. Up $(\uparrow)$ and down $(\downarrow)$ arrows indicate increase and decrease, respectively.

Cardiotoxicity during cisplatin treatment is also related to reactive oxygen species (ROS) overproduction, mitochondrial alterations, and inflammation. Therefore, we consider that cardiac injury could occur from cisplatin induced AKI and be a direct effect of cisplatin toxicity. 


\section{Cisplatin Uptake and Biotransformation in Tubular Cells}

Cis-diamine-dichloro platinum (II) (cisplatin) is an inorganic compound formed by an atom of platinum surrounded by chlorine and ammonia atoms in the cis position of a horizontal plane [44]. When chloride dissociates, cisplatin forms 1-2 intrastrand or 1-3 interstrand crosslinks with purine bases on the deoxyribonucleic acid strand (nDNA) [44]. This interaction produces nDNA adducts, which are essential modifications mediating the cytotoxic effect of cisplatin and leading to the G2 arrest of the cell cycle and apoptosis in the cancer cells $[45,46]$. Cisplatin also interacts with other nucleophilic sites, such as mitochondrial DNA (mtDNA), membrane proteins, endoplasmic reticulum (ER), and phospholipids $[47,48]$. It has been demonstrated that cisplatin binds more preferentially to mtDNA than to nDNA, because cisplatin is a positively charged metabolite that preferentially accumulates within negatively charged mitochondria [47,49] (Figure 2).

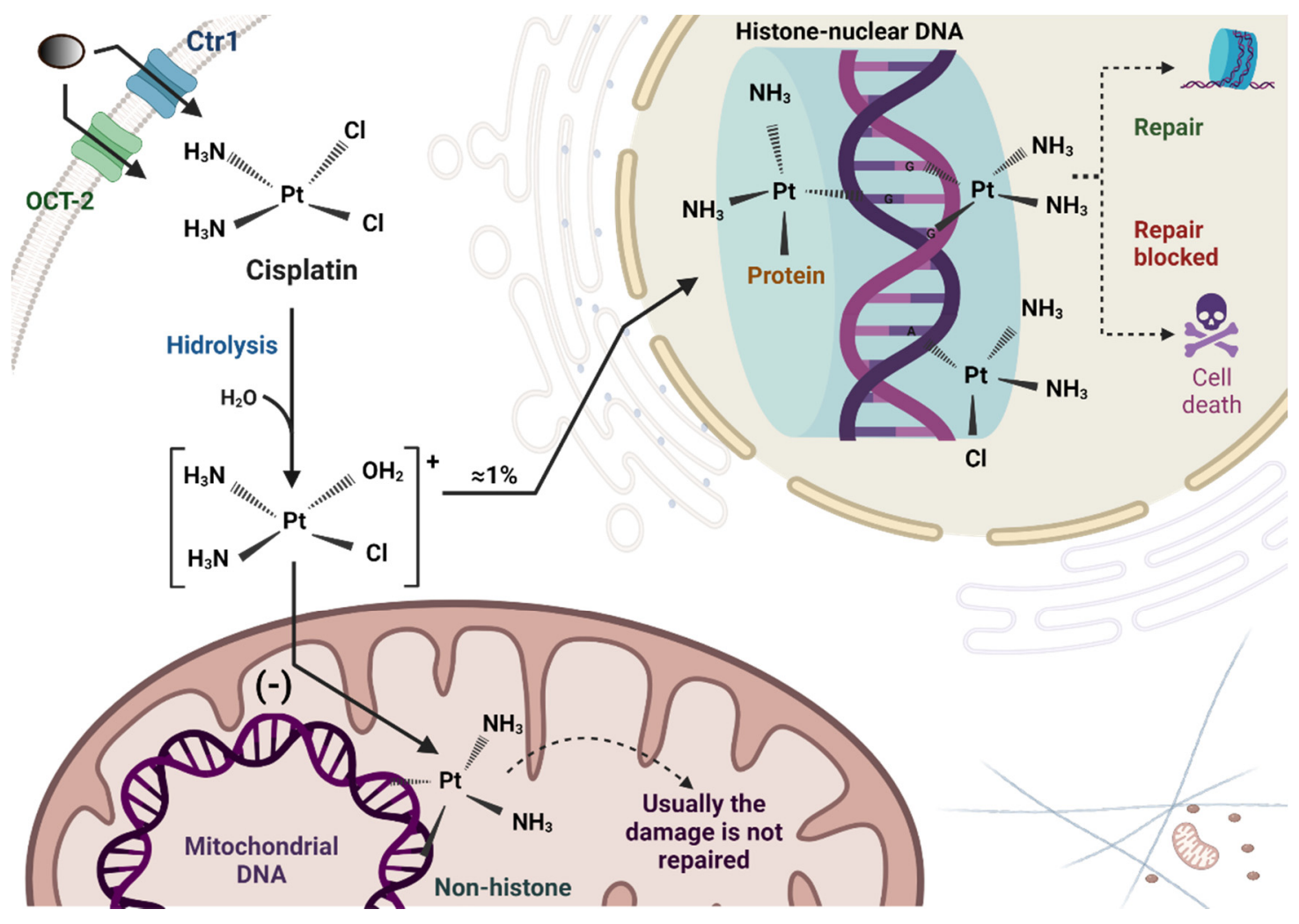

Figure 2. Interaction of cisplatin with deoxyribonucleic acid (DNA). When cisplatin enters cells, it becomes hydrated to form positively charged species. Approximately $1 \%$ of hydrated cisplatin forms adducts with nuclear DNA (nDNA) by joining the purine centers, mainly guanine. However, most intracellular cisplatin binds to nucleophilic sites in other molecules, such as mitochondrial DNA (mtDNA). Cisplatin binds to the mtDNA with more affinity than nDNA, and the lack of repair, the lack of histones, and the negative charge within the mitochondria make this organelle susceptible to damage. Ctr1: copper transport protein 1, OCT-2: basolateral organic cation transporter. Created with biorender.com (with copyright permission from biorender.com).

Cisplatin has a low molecular weight and is uncharged; therefore, it is freely filtered at the glomerulus. Consequently, there is an uptake of the drug by renal tubular cells that reaches high concentrations in the PTCs of the S3 segment, an important site of cisplatin induced renal damage; however, cisplatin also injures the distal tubule and collecting duct in a dose dependent manner [50]. Cisplatin is transported from basolateral to apical transport, linking the toxicity that it may cause to the tubular epithelium [25]. Cisplatin enters into the tubular cells by passive diffusion or by cellular transporters, such as copper transport protein 1 (Ctr1); the basolateral organic cation transporter 2 (OCT-2), which is highly expressed in renal tubular cells [25,47]; and the less explored volume regulated 
anion channels (VRAC) [26]. The multidrug and toxin extrusion 1 (MATE-1) mediates the secretion of cisplatin into the urine, and cisplatin induced nephrotoxicity is increased with the reduced activity of MATE- 1 and increased activity of OCT-2 [51,52].

When cisplatin undergoes metabolic activation in the kidney cells, it becomes a more potent toxin $[47,53]$. The dissociation of one of the chlorines from the cisplatin due to the aquation inside the cell results in a positive charge on the platinum that will attract the negatively charged sulfur on the cysteine moiety of the antioxidant peptide glutathione $[47,54]$, significantly reducing their levels. The formation of glutathione conjugates in the circulation passes through the kidney, and they are cleaved to cysteinyl-glycineconjugates by gamma-glutamyl transpeptidase (GGT), which is highly expressed on the surface of the PTCs [54]. GGT cleaves gamma-glutamyl bonds in extracellular glutathione and glutathione-conjugates $[53,54]$. The cysteinyl-conjugates are further metabolized to cysteine-conjugates by aminopeptidases, and then transported into the PTCs, where they are further metabolized by cysteine-S-conjugate beta lyase to the highly reactive thiols [53].

\subsection{Cisplatin Induced Mitochondrial Dysfunction in the Kidney}

Different studies have shown the role of mitochondrial dysfunction in cisplatin induced AKI [55-57]. PTCs have a high metabolic rate; therefore, they contain many mitochondria [58-60]. Cisplatin accumulates in the mitochondria of renal PTCs and forms crosslinks with mtDNA and proteins [25]. Recent evidence using a platinum selective fluorescent probe has shown that the Cytochrome c oxidase copper chaperone 17 (COX17), a mitochondrial intermembrane enzyme involved in copper transfer [61], mediated the mitochondrial internalization of cisplatin in HeLa cells [62], suggesting a mechanism by which mitotoxicity may occur [63].

Increasing evidence has proved that only a small amount of cellular platinum is bound to nDNA ( 1\%) [46], and other targets, such as the electron transport system (ETS), mtDNA, and the endoplasmic reticulum, have been suggested as participants of the cisplatin induced apoptosis, in addition to nDNA damage [48]. Furthermore, mtDNA is a target more susceptible to the formation of adducts due to three main characteristics: (1) the low decomposition activity of cisplatin-mtDNA adducts, (2) a higher mutation rate in contrast to nDNA and, (3) the superoxide radical $\left(\mathrm{O}_{2} \bullet^{-}\right)$produced in the mitochondria cannot pass through the membranes $[31,58,64]$. Other mechanisms, including excessive ROS production, nDNA damage response [57], reduction in membrane potential, impairment of the mitochondrial redox balance, apoptosis, and inflammation, have also been proposed as the main contributors to the pathogenesis of cisplatin induced renal injury $[22,56,58,65]$ (Figure 3).

(a) ROS: During oxidative phosphorylation in the mitochondria, electrons leak from mitochondrial complexes in the ETS, resulting in the partial reduction of oxygen $\left(\mathrm{O}_{2}\right)$; and this process leads to a small amount of ROS in the form $\mathrm{O}_{2} \bullet-$ [66-68]. ROS are physiologically necessary for cells' functions $[69,70]$, but their overproduction reduces ETS efficiency, leading to diminished mitochondrial membrane potential and mitochondrial dysfunction [71]. Mitochondria are one of the principal endogenous sources of ROS, and, after cisplatin treatment, mitochondria become uncontrolled intracellular ROS producers $[41,72,73]$. ROS impair electron flow through the ETS, producing even more ROS by mitochondrial complexes or Krebs cycle dehydrogenases [74,75]. Recent studies in animals (see Table 2) have shown that a reduction in mitochondrial ATP production also favors ROS production by the nicotinamide adenine dinucleotide phosphate hydrogen (NADPH) oxidases (Nox), specifically by Nox4 [76], which is also present in the mitochondria. ROS overproduction reduces the antioxidants in the mitochondria, such as glutathione peroxidase (GPx) and manganese superoxide dismutase (MnSOD) [40,42,77,78].

The dysregulation of mitochondria's functional and structural integrity is the critical early event responsible for tissue injury in cisplatin induced AKI [79]. ROS directly affect protein synthesis and structure, DNA synthesis, and cell repair mechanisms [80]. ROS can lead to a vicious circle in which ROS species can activate the mitochondrial membrane 
pores, leading to mitochondrial dysfunction and further ROS release $[67,81]$. Besides, ROS can damage mitochondrial molecules either at or near the site of their formation [31]. Electrophilic toxic metabolites and ROS may increase oxidative damage and lead to proximal tubule injury [5].

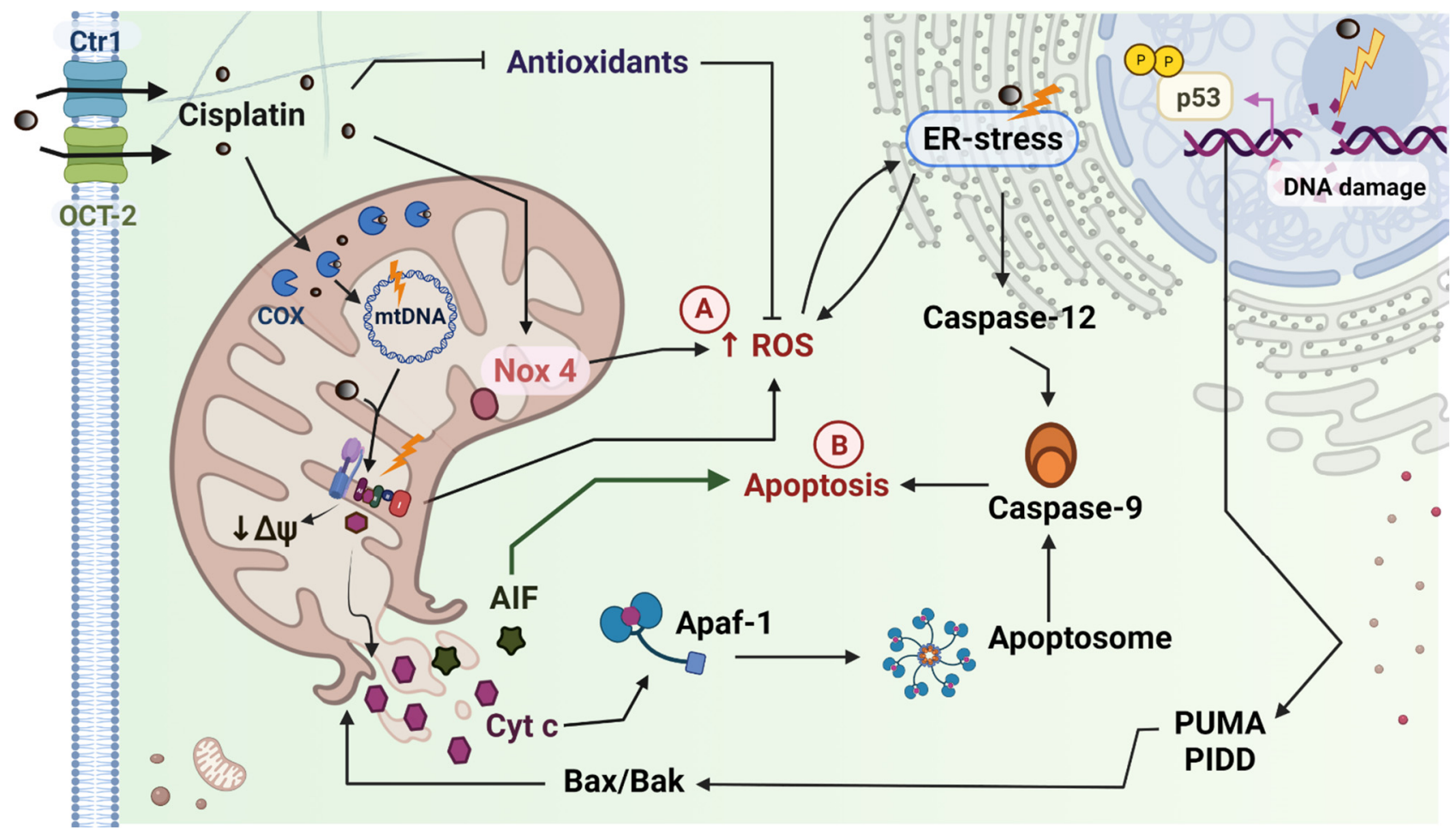

Figure 3. Cellular mechanisms related to cisplatin induced oxidative damage and apoptosis. Cisplatin enters the cells by passive diffusion or by cellular transporters (copper transport protein 1 [Ctr1] and the basolateral organic cation transporter [OCT-2]). The accumulation of cisplatin inside the cells leads to nDNA and mtDNA alterations, disturbances in the electron transport system (ETS), and the activation of NADPH oxidases (Nox). Cisplatin could enter the mitochondria through COX17, an enzyme in the intermembrane space that handles the uptake of copper. Cisplatin decreases antioxidant enzymes, such as glutathione peroxidase (GPx) and superoxide dismutase (MnSOD), leading to increased reactive oxygen species (ROS) production and promoting oxidative stress. ROS led to endoplasmic reticulum (ER) stress that, in turn, enhances the production of ROS. Moreover, the response to nuclear DNA damage or cellular tension leads to the activation of p53 by its phosphorylation. Subsequently, p53 phosphorylated activates p53 induced protein with a death domain (PIDD) and the p53 upregulated modulator of apoptosis (PUMA). PUMA in the cytoplasm activates pro-apoptotic proteins, such as Bcl-2-like protein 4 (Bax) and Bcl-2 homologous antagonist/killer (Bak), that form a pore in the outer membrane of the mitochondria, allowing the release of cytochrome $\mathrm{c}(\mathrm{Cyt} \mathrm{c}$ ) and apoptosis-inducing factor (AIF). Cyt $\mathrm{c}$ in the cytosol induces the oligomerization of apoptosis protease-activating factor-1 (Apaf-1). Apaf-1, Cyt c, and adenosine triphosphate (ATP) form the apoptosome, which activates caspase-9. Activated caspase- 9 leads to the processing of effector caspase, triggering the last phases of apoptosis. Caspase- 9 can also be activated by caspase-12, which is promoted by endoplasmic reticulum (ER) stress. After mitochondria release AIF, it accumulates in the nucleus to induce apoptosis in a caspase independent manner (green line). $\Delta \psi$ : membrane potential, mtDNA: mitochondrial deoxyribonucleic acid, COX17: Cytochrome c oxidase copper chaperone. Created with biorender.com (published with permission from biorender.com).

Nox4 is highly expressed in the kidney and is substantially increased by cisplatin in vivo and in vitro. Nox4 mediated ROS generation aggravates cisplatin induced nephrotoxicity by promoting ROS mediated programmed cell death and inflammation [82]. In vitro cisplatin induced AKI also worsens with high glucose (as occurs in diabetic patients), leading to the overexpression of Nox4 and increasing ROS levels and inflammation even more [83]. This redox disturbance produces oxidative stress, defined as an imbalance in the excessive generation of ROS and impaired scavenging of ROS [66,69,80,81]. Some 
studies have demonstrated that using treatments with antioxidants ameliorates the nephrotoxic effects of cisplatin in the renal tissue [42,46,56,84] and tubular cells [77], suggesting that the development of new therapies against mitochondrial oxidative stress during the pathogenesis of cisplatin induced toxicities may be beneficial for cancer patients.

(b) Apoptosis: Mitochondrial apoptotic pathways (intrinsic pathways) are deeply involved in cisplatin induced AKI [85]. In response to cellular stress, tumor protein (p53) and its phosphorylation is induced in PTCs and upregulates components of several apoptosis pathways, such as a p53-induced protein with a death domain (PIDD) and p53 upregulated modulator of apoptosis (PUMA), resulting in cell dysfunction and, eventually, apoptosis. The suppression of the expression and activation of Poly (ADP-Ribose), Polymerase (PARP1), p53, and the histone $\gamma-\mathrm{H} 2 \mathrm{AX}$, has shown protection against cisplatin-induced AKI in mice [8]. On the other hand, Bcl-2 family proteins; Bcl-2-associated X protein (Bax) and Bcl-2 homologous antagonist/killer (Bak) form pores on the outer mitochondrial membrane (OMM), resulting in the release of apoptogenic factors, such as cytochrome $\mathrm{c}$ (Cyt c), apoptosis-inducing factor (AIF), the second mitochondria derived activator of caspase (Smac)/direct inhibitor of apoptosis binding protein with low pI (DIABLO), and endonuclease G. Cisplatin not only activates several signaling pathways, such as mitogen-activated protein kinase (MAPK), p53, p21, caspase-3, Bcl-2, and renal tubular cell damage [86], but also may involve other mitochondrial processes; for example, damage to mitophagy [78] and mitochondrial dynamics $[87,88]$.

Mitochondrial fission can be induced by mitochondrial membrane depolarization, which also triggers mitochondrial permeabilization and apoptogenic factors [87]. The impairment of mitochondria structural integrity ultimately results in ATP depletion and cytoskeletal changes, leading to the disintegration of the brush border, loss of cell-cell contact, and tubular epithelial cell detachment in the kidney $[87,89]$.

Table 2. Cisplatin administration induces dose-time alterations in the rodents' kidneys.

\begin{tabular}{|c|c|c|c|c|}
\hline Model & $\begin{array}{l}\text { Cisplatin Dose/Time } \\
\text { Administration }\end{array}$ & $\begin{array}{l}\text { Kidney } \\
\text { Alterations }\end{array}$ & $\begin{array}{c}\text { Other } \\
\text { Alterations }\end{array}$ & Reference \\
\hline $\begin{array}{l}\text { Male Wistar rats } \\
\quad(200-250 \mathrm{~g})\end{array}$ & $\begin{array}{l}5 \mathrm{mg} / \mathrm{kg}(\mathrm{i} . \mathrm{p}) \\
3 \text { days }\end{array}$ & $\begin{array}{l}\uparrow \text { SCr and BUN } \\
\text { Swelling of the epithelial cells from CPTs. } \\
\text { Extensive cytoplasmic vacuolization } \\
\text { detached necrotic cells and cellular debris } \\
\text { in the tubular lumen. } \\
\downarrow \text { RCI, ADP/O ratio, ATP synthase activity, } \\
\text { mtMP, OPA-1, and Sirt-3. }\end{array}$ & $\begin{array}{l}\text { Mitochondria alterations: } \\
\uparrow \text { FIS- } 1 \text {, swelling, rupture } \\
\text { of cristae, and autophagic } \\
\quad \text { bodies in CPTs. } \\
\text { Decreased state III and I of } \\
\text { the ETS as well as for RCI } \\
\text { and ADP/O ratio. State } 4 \\
\text { was unchanged. }\end{array}$ & $\begin{array}{l}\text { Ortega-Domínguez } \\
\text { et al. [56] }\end{array}$ \\
\hline $\begin{array}{l}\text { Male 10-week-old } \\
\text { C57BL/6J mice }\end{array}$ & $\begin{array}{c}10 \mathrm{mg} / \mathrm{kg} \text { (i.p) } \\
7 \text { days }\end{array}$ & $\begin{array}{c}\uparrow \text { BUN and tubular necrosis } \\
\uparrow \text { mRNA expression of injury markers: } \\
\text { NGAL and KIM-1. Increased DHE } \\
\text { oxidation. }\end{array}$ & $\downarrow$ Body weight & Mapuskar et al. [45] \\
\hline $\begin{array}{l}\text { Male 8-weeks old } \\
\text { C57BL/6N mice }\end{array}$ & $\begin{array}{c}16 \mathrm{mg} / \mathrm{kg} \text { (i.p) } \\
4 \text { days }\end{array}$ & $\begin{array}{l}\text { } \uparrow \mathrm{BUN}, \mathrm{SCr} \text {, and apoptosis. } \\
\text { Histopathological alterations: loss of the } \\
\text { brush border, tubular cell loss, and cast } \\
\text { formation. }\end{array}$ & $\uparrow$ Autophagy & Zhu et al. [78] \\
\hline $\begin{array}{l}\text { BALB/c mice } \\
\quad(20-25 \mathrm{~g})\end{array}$ & $\begin{array}{c}20 \mathrm{mg} / \mathrm{kg}(\mathrm{i} . \mathrm{p}) \\
3 \text { days }\end{array}$ & $\begin{array}{c}\text { 个 BUN, SCr, MDA, and apoptosis. } \downarrow \text { GSH, } \\
\text { SOD, CAT. } \\
\text { Kidney lesions, whitening, and tubular } \\
\text { injury. }\end{array}$ & $\begin{array}{l}\uparrow \text { mortality, Nrf- } 2, \mathrm{HO}-1 \text {, } \\
\text { and NQO- } 1 \text {. } \\
\uparrow \mathrm{TNF}-\alpha \text { and IL- } 1 \beta \text { in the } \\
\text { renal tissue. }\end{array}$ & Zhang et al. [73] \\
\hline $\begin{array}{l}\text { Male 8-12 weeks } \\
\text { old C57BL/ } 6 \text { mice } \\
\text { 22-24 g }\end{array}$ & $\begin{array}{c}20 \mathrm{mg} / \mathrm{kg} \text { (i.p) } \\
3 \text { days }\end{array}$ & $\begin{array}{c}\uparrow \text { BUN, SCr, KIM- } 1 \text { mRNA, and } \\
\text { proinflammatory cytokines: IL-6, IL-1 } \beta \text {, } \\
\text { TNF- } \alpha \text {, and MCP-1. Tubular dilation, } \\
\text { protein casts, and loss of proximal brush } \\
\text { border. } \\
\uparrow \text { kidney size } \\
\text { Pale appearance }\end{array}$ & - & Yang et al. [85] \\
\hline
\end{tabular}


Table 2. Cont.

\begin{tabular}{|c|c|c|c|c|}
\hline Model & $\begin{array}{l}\text { Cisplatin Dose/Time } \\
\text { Administration }\end{array}$ & $\begin{array}{l}\text { Kidney } \\
\text { Alterations }\end{array}$ & $\begin{array}{c}\text { Other } \\
\text { Alterations }\end{array}$ & Reference \\
\hline $\begin{array}{l}\text { Male 8-week-old } \\
\text { C57BL/6 mice }\end{array}$ & $\begin{array}{l}30 \mathrm{mg} / \mathrm{kg}(\mathrm{i} . \mathrm{p}) \\
2 \text { days }\end{array}$ & $\begin{array}{c}\uparrow \mathrm{SCr}, \mathrm{BUN} \text {, and apoptosis. } \\
\text { Severe damage with cast formation, } \\
\text { vacuolization, and dilation in renal tubules. }\end{array}$ & $\begin{array}{l}\text { RPTCs treated with } 20 \mu \mathrm{M} \\
\text { of cisplatin for } 16 \mathrm{~h} \\
\text { produced apoptotic cells } \\
\text { with nuclear condensation } \\
\text { and fragmentation. }\end{array}$ & Wu et al. [8] \\
\hline $\begin{array}{l}\text { Male 10-week-old } \\
\text { C57BL/6 mice }\end{array}$ & $\begin{array}{c}20 \mathrm{mg} / \mathrm{kg} \text { (i.p) } \\
8 \text { days }\end{array}$ & 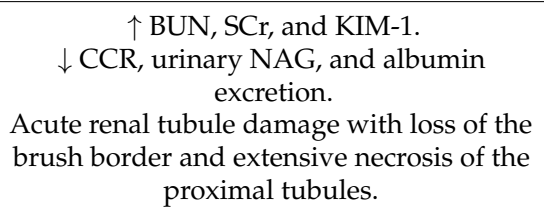 & $\begin{array}{l}\uparrow \text { cleaved caspase-3, Bax, } \\
\text { and p53. } \\
\downarrow \text { levels of Bcl-2. }\end{array}$ & Luan et al. [90] \\
\hline
\end{tabular}

Abbreviations: ADP/O: adenosine diphosphate/oxygen, Bax: Bcl-2-Associated X Protein, Bcl-2: B-cell lymphoma 2 family of proteins, BUN: blood urea nitrogen, CAT: catalase, CCR: creatinine clearance rate, CPTs: convoluted proximal tubules, Cr: creatinine, $\mathrm{CrCl}$ : creatinine clearance, DHE: dihydroethidium, ETS: electron transport system, FIS-1: mitochondrial fission 1 protein, GSH: glutathione, HO-1: heme oxygenase, IL-: interleukin, KIM-1: kidney injury molecule-1, MCP-1: monocyte chemoattractant protein-1, MDA: malondialdehyde, MMP-: matrix metalloproteinases, mtMP: mitochondrial membrane potential, NAG: N-acetyl-beta-(D)-glucosamine, NGAL: neutrophil gelatinase-associated lipocalin, NQO-1: quinone oxidoreductase, Nrf-2: nuclear factor erythroid 2-related factor, OPA-1: optic atrophy type 1, PCr: plasma creatinine, Pi: phosphate, RCI: respiratory control, RPTCs: renal proximal tubular cells index, SCr: serum creatinine, Sirt-3: sirtuin 3, SOD: superoxide dismutase, TNF- $\alpha$ : tumor necrosis factor-alpha, mRNA: messenger ribonucleic acid. Up ( $\uparrow)$ and down $(\downarrow)$ arrows indicate increase and decrease, respectively.

\subsection{Cisplatin Induced Mitochondrial Dysfunction in the Heart}

Cardiomyocytes are cells with a high demand for energy [91]. They consume approximately $8 \%(\sim 6 \mathrm{~kg})$ of ATP a day, and nearly $90 \%$ of cellular ATP is used to meet the high requirements for contraction and relaxation. Consequently, about $75 \%$ of a cell's volume is occupied by mitochondria [92-94]. The high number of mitochondria in the heart is a feature that can be correlated with enhanced ROS levels during pathologies that produce dynamic changes, such as mitochondrial fragmentation and autophagy [95], ultimately leading to the damage of the myocardium [66]. The mitochondria provide the required energy to the heart, depending upon the continuous supply of oxygen obtained by coronary flow [91]. In contrast, when the heart is failing, it switches from fatty oxide metabolism $(>95 \%)$ to glycolytic metabolism $[93,96]$.

In animals, cisplatin also induces several cardiac alterations, such as disorganized cardiac muscle fibers, pyknotic nuclei, collagenous fibers deposition, tumor necrosis factoralpha (TNF- $\alpha$ ) production, and a significant increase in the number of p53 positive nuclei. In addition, cardiomyocytes also show disorganized myofibrils, swollen or disrupted mitochondria, and widening intercalated discs [34]. An antioxidant (ginger) treatment showed a marked improvement in cardiac histology and ultrastructure through antiapoptotic, antioxidant, and anti-inflammatory properties. Similar results were shown in a model of cisplatin toxicity with male albino Balb/c mice [40]. There was a reduction in antioxidant systems and an increase in oxidative stress and damage in cardiac enzymes. Treatment with two antioxidants (green tea extract and vitamin E) improved biochemical and histological parameters and oxidative stress. In addition, it has been shown that the decrease in nitrosative stress and lipid peroxidation produced by an inhibitor of the mesenchymal-epithelial transition factor (c-Met) has protected against the nephrotoxicity and cardiotoxicity induced by cisplatin- or doxorubicin [97].

Cui et al. used a database analysis of the potential pathways. They found that the cardioprotective effect was mainly associated with nuclear factor erythroid 2 related factor 2 (Nrf-2)/heme-oxygenase-1 (HO-1) and p38-MAPK pathways, suggesting that protection against oxidative stress injury and several transcription factors are the main contributors to intracellular signal transduction pathways to cardiac oxidative stress during cisplatin therapy. Cisplatin induced cardiotoxicity associates with oxidative stress and increases gene expression of proinflammatory cytokines, such as TNF- $\alpha$ and tumor necrosis factor receptor 1 (TNFR-1), possibly mediating the relationship between Nrf-2 and MAPK [41]. TNF- $\alpha$ and TNFR-1 may act as death receptors that bind to the cells' plasma membrane and 
lead to the recruitment and activation of caspase-8, which activates downstream caspases to induce apoptosis [22].

ROS mediated mitochondrial dysfunction contributes to heart failure [93]. For example, after damage, cardiomyocytes show increased amounts of small and fragmented mitochondria $[98,99]$. ROS also increases cell wall permeability, with subsequent LDH leakage acting as a marker of cell death [40]. When cells are damaged, ATP production declines and results in cell alterations or cell death. After disruption, mitochondria release components such as mtDNA, which may act as damage associated molecular patterns (DAMPs), leading to proinflammatory immune responses, such as activating dendritic cells and macrophages in the heart $[100,101]$. The ROS overproduction induced by cisplatin also activates Bax, which is then transported to the outer mitochondrial membrane, changing its permeability and reducing B-cell lymphoma 2 (Bcl-2) levels in the heart tissue, consequently increasing the oligomerization of Bax/Bak and producing apoptosis of myocardial cells [43]. These studies suggest that oxidative stress and mitochondrial dysfunction (Table 2) are the first mediators of cardiac alterations during cisplatin treatment, and that ROS scavengers, antioxidants, or inhibitors of mitochondrial dysfunction could play an essential role in stopping secondary disturbances.

\section{Therapeutic Approaches to Mitigate the Nephrotoxic Effects of Cisplatin}

In clinics, to attenuate the nephrotoxic effects of cisplatin, patients receive active hydration and mannitol administration to increase the rate of cisplatin excretion [21,28]. In addition, other experimental approaches have been demonstrated to reduce the nephrotoxic effects of cisplatin. Some antioxidants, such as allopurinol (a xanthine oxidase inhibitor) in combination with ebselen (a glutathione peroxidase mimetic), have demonstrated renoprotective effects in rats [102]. Similar results were found using resveratrol and beta-lapachone $[28,103,104]$. Other antioxidants, such as slymarin, naringernin, vitamin C, and vitamin E, have been shown to protect the kidney's function in animal studies [105]. On the other hand, salicylates are anti-inflammatory drugs that inhibit cyclooxygenase activity and prostaglandin synthesis, reducing the renal inflammatory response in cisplatin toxicity models [106]. Finally, fibrates (inhibitors of the accumulation of free fatty acid and suppressors of apoptosis) have also been shown to prevent cisplatin induced renal toxicity in in vivo and in vitro models [28].

Since mitochondrial alterations and oxidative stress are primarily responsible for the AKI and cardiorenal syndrome induced by cisplatin, here we discuss the potential use of mitochondrial transplantation (MT) $[91,107,108]$ as a complementary approach for their management.

\subsection{Mitochondrial Transplantation as a Novel Therapy for Mitochondrial Dysfunction}

The need to prevent or alleviate mitochondrial alterations, especially those elicited by oxidative stress and mitochondrial dysfunction, demands new therapeutic strategies in molecular and cellular medicine that go further in pharmacotherapy. MT [91,107,108], or mitotherapy [109], is a novel technique whose first aim is to replace dysfunctional mitochondria with healthy mitochondria $[91,92,107,110,111]$. Transplanted mitochondria can incorporate into mammalian cells and contribute to changes in the bioenergetics profile [112], the rescue of respiratory and cell functions, induced Treg cell differentiation [113], and the transfer of mitochondrial genes, inducing metabolic reprogramming [92,108,114]. In the last decade, many experimental studies have obtained these tiny bean-shaped organelles of tissues without damage, such as pectoralis muscle, heart, liver, or kidneys, cell lines [91,92,107,115,116], platelets [117] and mesenchymal stem cells (MSCs) [79,89,95].

Although mitochondrial internalization has been observed in several cells, internalization mechanisms on injury context and delivery strategies are both fields that remain to be explored. In cellular communication, mitochondria can traverse cell boundaries and be horizontally transferred between cells through different mechanisms, such as tunneling nanotubes, extracellular vesicles, cellular fusion and GAP junctions [114]. At present, the 
molecular mechanisms by which damaged cells acquire mitochondria from other cells are unknown [118].

In vitro, mitochondria have been incorporated through tunneling nanotubes (mainly constituted by actin filaments) [118-120] and macropinocytosis [116] from one cell to another (Figure 4B). Mitochondria from cardiomyocytes communicate with each other through "kissing" (transference of contents between adjacent mitochondria) and nanotunneling (transference in long range mitochondrial pairs). "Kissing" is related to the minimal movement of mitochondria inside cardiomyocytes, suggesting other forms of communication in which mitochondria form dynamically continuous networks to exchange matrix or membrane contents [99]. In other studies of MT, isolated homogenous mitochondria were cocultured with human endometrial gland derived mesenchymal cells and incorporated through a macropinocytosis mechanism [116]. The exogenous mitochondria rescued the mitochondrial respiratory function and the cellular viability in mtDNA-depleted cells.

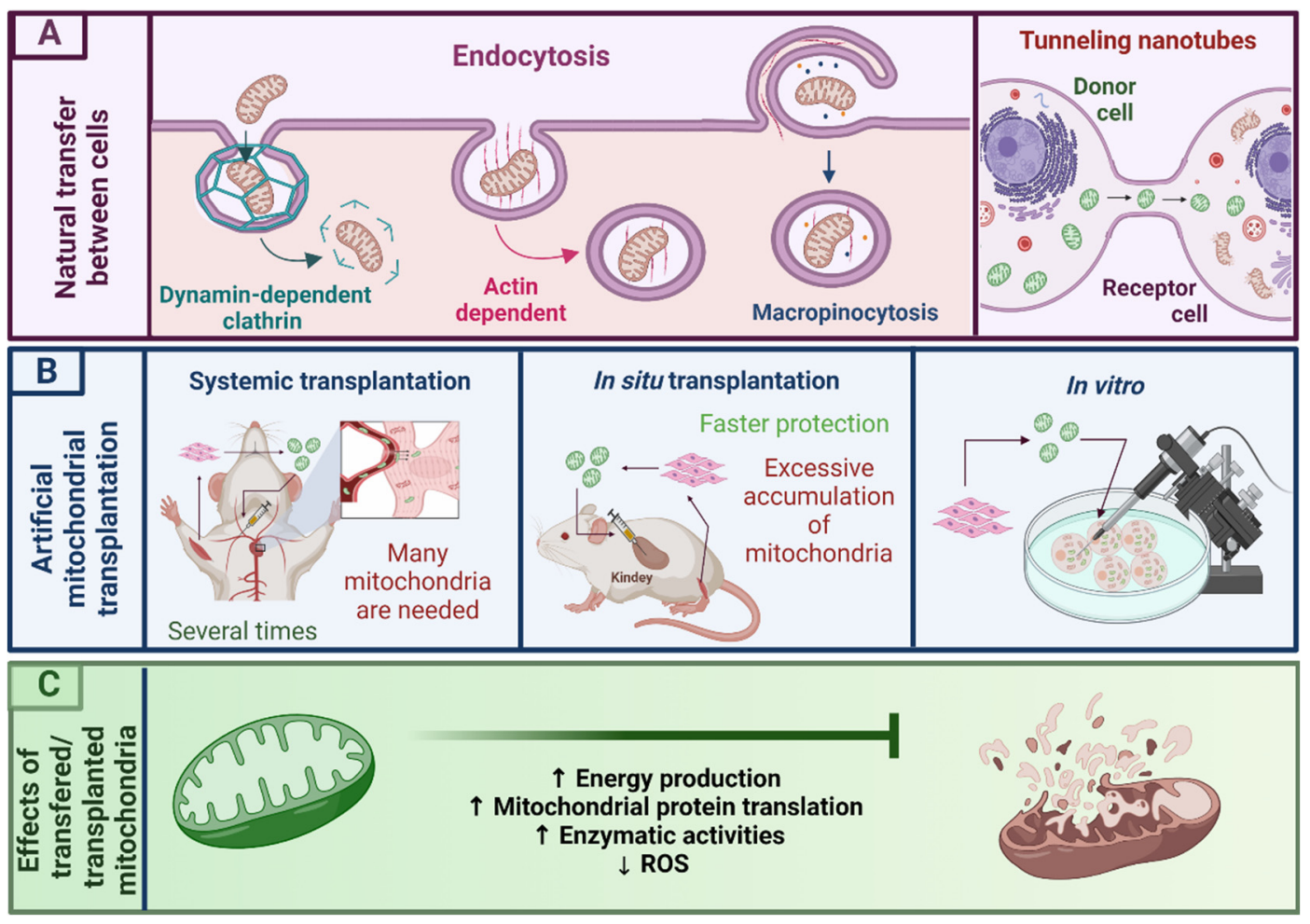

Figure 4. Mitochondrial transplantation (MT). (A) Natural transfer between cells. Depicted-possible internalization mechanisms of mitochondria in cells include dynamin dependent clathrin, actin dependent endocytosis, macropinocytosis, and tunneling nanotubes. (B) Artificial mitochondrial transplantation. Mitochondria can be incorporated into tissues by different techniques depending on the target tissue and the injury. In vivo transplantation routes include delivery of mitochondria to the bloodstream (systemic transplantation) and direct delivery to tissue (in situ transplantation). In vitro, MT can also be performed. (C) Effects of transferred/transplanted mitochondria. Mitochondrial transplantation increases energy production, mitochondrial protein translation, enzyme activities and decreased ROS. Created with biorender.com (with copyright permission from biorender.com).

MSCs primarily take up platelet derived mitochondria via dynamin dependent, clathrin mediated endocytosis [121], but MSCs have also been shown to donate mitochondria to neural stem cells (NSCs) through actin based intercellular structures and the mitochondrial motor protein Rho-GTPase 1 (Miro1) during cisplatin induced damage in vitro [101].

Pacak et al. [120] studied mitochondrial internalization mechanisms in cardiomyocytes using specific blockers for internalization mechanisms. The authors found that neonatal rat cardiomyocytes and autologous mitochondria coincubation was internalized through 
actin dependent endocytosis (Figure 4B) as soon as after $1 \mathrm{~h}$ of co-incubation. Transplanted mitochondria increased ATP content, oxygen consumption rates and replaced mtDNA in $\rho 0$ cells (cells devoid of mtDNA). Finally, using three dimensional, super resolution microscopy and transmission electron microscopy to determine the intracellular fate of exogenous mitochondria from human cardiac fibroblasts (HCF) in two lines of cells; human induced, pluripotent, stem cell derived cardiomyocytes; and primary cardiac fibroblasts, it was demonstrated that mitochondria incorporated into cardiac cells through an actin polymerization mechanism in a few minutes, and then transported to the endolysosomal system. Although, in this study, it was observed that some mitochondria were destined for degradation, most exogenous mitochondria escaped from endosomal and lysosomal compartments and fused with endogenous cardiac cell mitochondria, showing beneficial results [122].

The natural transference of mitochondria between cells led to the proposal of MT as a feasible therapy in different pathologies in which this organelle shows disturbances [118].

\subsection{Mitochondrial Isolation}

For a proper MT, there is a need for proper mitochondrial isolation to ensure their integrity and functionality; thereby, several methodologies have been described $[87,108,123]$.

Mitochondrial isolation must be short and efficient (usually $45-120 \mathrm{~min}$ ) for preventing prolonged surgical times in clinical practice [108], and the tissue used for obtaining the mitochondria must not have lesions or damage. Mitochondria isolation requires transferring the tissue in homogenizing buffers that closely depend on the needs of cells or tissues. $[116,124,125]$. Homogenizers need to provide sterilized and effective homogenization, allowing the consistent and uniform dissociation of the tissue. Tissue homogenates, such as those obtained from muscle, the liver or the heart, are usually subjected to brief digestion, generally with subtilisin $\mathrm{A}$, and the mixture can be passed through several disposable mesh filters or differential centrifugation $[87,91,111,123]$. Cells are usually ruptured on ice with strokes of 27 gauge and then differentially centrifugated [116,124,125]. Mitochondria cannot survive much time after extraction, and although many improvements in extraction protocols have reduced the time of extraction, some characteristics, such as temperature, respiration buffer, and counting methods, need to be taken into account to improve mitochondrial survival $[91,93,123]$.

Once the mitochondria to be transplanted are obtained, they can be incorporated into the tissues with experimental techniques that depend on the site and the type of injury. In in vivo studies, mitochondria have been transplanted through different routes; for example, during administration in the blood circulation (systemic transplantation), mitochondria have been injected through coronary arteries, renal arteries, and the tail vein $[109,110,126,127]$. Mitochondria have also been transplanted directly to the tissue (in situ transplantation) in the renal capsule, or directly into the myocardium $[45,87,89,100,111]$.

MT is an emergent field based on the delivery of mitochondria from autologous or nonautologous sources to treat diseases related to mitochondrial damage or dysfunction [128]. MT could be a possible option for being used in clinical settings where mitochondria are mainly damaged [81]. MT has been shown to provide a therapeutic benefit, because donated mitochondria have been shown to restore mitochondrial function [128]. The replacement of damaged mitochondria with respiratory competent mitochondria has increased energy production, mitochondrial protein translation, enzyme activities, mtDNA replacement, and ROS reduction (Figure 4C) [81,107,108,110,111,126]. In addition, MT has rescued the mitochondrial respiratory function and improved the cellular viability of mtDNA depleted cells [116]. Other studies have demonstrated that mitochondrial fractions, mtDNA or messenger ribonucleic acid (mRNA), exogenous ATP, or adenosine diphosphate (ADP) do not offer any cytoprotection [92,107,123,129], even though they can act as DAMPs $[93,130]$. The inflammatory response produced by the fragments of mitochondria suggests that these organelles should be intact to promote beneficial effects. There are no negative bioenergetic consequences after MT; in fact, newly transplanted mitochondria 
are adopted by the host and show improved bioenergetic consequences during the early stages of damage [112].

\subsection{MT in Pathology Induced Mitochondrial Dysfunction}

Several animal studies are showing the beneficial result of MT in animal models of disease. The applications of MT to different pathologies, such as ischemia-reperfusion (I/R) in the heart, in I/R and nephrectomy in the kidney as well as in nonalcoholic fatty liver disease, have been demonstrated to produce the recovery of the tissues by improving the respiration of mitochondria, reducing the levels of inflammation, and decreasing apoptosis of the cells. The following section will specifically discuss these assertions.

\section{(a) Liver}

MT has shown the therapeutic effect of exogenous mitochondria (isolated from HepG2 cells), transplanted in the tail vein, against high fat, diet induced fatty liver in mice. Mitochondria could directly target tissue cells, decreased serum aminotransferase and cholesterol levels. Mitochondria also attenuated the intrahepatic excessive lipid accumulation, the oxidation injury of the fatty liver mice, improved energy production hepatocyte function [109]. These studies suggest that MT could be a potential treatment to treat mitochondrion associated liver diseases.

\section{(b) Kidney}

Jabbari et al. [87] used an in vivo model of AKI (right nephrectomy + left kidney I/R), and the authors studied the effects of autologous mitochondria obtained from pectoralis major muscle cells and transplanted in injured kidney cells through an injection to the renal artery. MT prevented renal tubular cell death, restored renal function, ameliorated kidney damage, and led to the regeneration of renal tubules, decreasing I/R-induced apoptosis.

\section{(c) Heart}

Many studies have pointed out the use of MT in alterations produced by I/R injuries in the heart, showing beneficial results.

McCully et al. [107] conducted a study in an in vivo myocardial infarction model (through I/R) in New Zealand white rabbits where mitochondria (isolated from donor rabbit left ventricular tissue) were transplanted into myocardial tissue one minute before reperfusion. MT reduced the ischemic tissue damage and led to functional recovery. This study also demonstrated enhanced cardioprotection during myocardial infarct by reducing necrosis markers, apoptosis, and cardiac markers such as cardiac troponin I (cTnI) and creatine kinase-MB (CK-MB). Finally, injected mitochondria were present and viable after $120 \mathrm{~min}$ of reperfusion and were distributed from the epicardium to the subendocardium, highlighting their function in ischemic functional recovery and cellular viability. Similar to these findings, Masusawa et al. [129] observed the reduction in infarct levels due to an autologous MT (mitochondria obtained from the pectoralis major muscle) after I/R injury in the heart. MT increased the precursor metabolites required for cellular respiration, enhanced oxygen consumption, and induced cytokine mediators. Mitochondria were internalized into cardiomyocytes two hours after transplantation, and the cardiac protective effects were preserved for more than 28 days, suggesting that mitochondria are internalized depending on the extension of the damage.

Kaza et al. [131] demonstrated the clinical efficacy of autologous MT (isolated from skeletal muscle tissue) to translate it into human applications. They used Yorkshire pigs subjected to regional ischemia (RI) by temporarily snaring the circumflex artery. After 24 min of RI, they injected $(8 \times 0.1 \mathrm{~mL})$ a vehicle containing mitochondria into the area at risk, then the snare was released, and the animals were followed for 4 weeks. MT reduced the infarct size and the damage to heart tissue. There were no changes in levels of CK-MB and cTn1, as well as in immune, inflammatory, and cytokine activation markers.

Cowan et al. [110] used a heterologous MT (mitochondria isolated from human adult cardiac fibroblasts) in rabbit hearts that underwent focal ischemia for $30 \mathrm{~min}$, followed by 
reperfusion. Mitochondria were injected through the coronary vasculature to increase the potential of this approach. They noted that many mitochondria were found in the interstitial spaces, but some mitochondria were co-localized within cardiomyocytes. Mitochondria could be successfully delivered into the myocardium by vascular perfusion, and MT reduced myocardial infarct size and enhanced postischemic functional recovery [110].

Moskowitzova et al. [132] improved cold ischemia time (CIT) by transplanting mitochondria in the heart (isolated mitochondria from gastrocnemius muscle) by antegrade injection in the coronary arteries toward the coronary ostium. The mitochondria were first delivered just before CIT, to protect from ischemia, and then again $5 \mathrm{~min}$ before reperfusion. MT reduced heart graft failure in the post-transplantation period and prolonged CIT by up to $29 \mathrm{~h}$. In addition, MT enhanced tissue viability, reduced neutrophil infiltration, prolonged heart graft function, beating score, ejection fraction, and shortening function

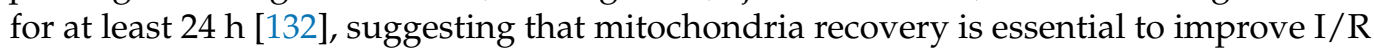
disturbances in the heart.

Emani et al. [111] demonstrated promising results in a human application in which they made an MT using autologous mitochondria harvested from nonischemic skeletal muscle in pediatric patients with cardiac I/R injury through several direct myocardium injections. Although the authors observed the recovery of myocardial function after extracorporeal membrane oxygenation support, they did not study the involved mechanisms of protection, demanding the need for more specific studies to elucidate whether it would be possible to isolate healthy mitochondria and utilize them safely in clinical practice [133].

\subsection{MT in Drug Induced Mitochondrial Dysfunction}

The applications of MT in drug induced pathologies have been a very recent attempt that has shown promising results in organs such as the kidney, liver and heart:

(a) Liver

Recently, Ulger et al. [134] used MT in the acetaminophen-liver toxicity model (isolated mitochondria obtained from MSCs and delivered to the liver via the portal circulation through an injection into the spleen). MT improved tissue morphological structure and liver function. The plasma levels of alanine aspartate aminotransferase, apoptotic cells, and the total oxidant levels were decreased. It is interesting to mention that this study evaluated the comparison between $\mathrm{N}$-acetylcysteine (an antioxidant and anti-inflammatory drug) and the MT, observing that $\mathrm{N}$-acetylcysteine provided partial improvement compared to MT, which suggests that exogenous mitochondria could be a more effective therapy in treating drug induced liver toxicity.

\section{(b) Kidney}

Konari et al. [89] demonstrated that, in an in vivo model of diabetic nephropathy induced with streptozotocin (see Table 3), mitochondria derived from MSCs and directly injected under the renal capsule of the left kidney were rapidly incorporated (within $24 \mathrm{~h}$ ) in PTECs, and the mitochondria suppressed ROS production by recovering superoxide dismutase 2 (SOD2) levels and inhibiting apoptosis through the increased expression of Bcl2 family proteins (Bax)/Bcl-2. In addition, these findings also supported that mitochondrial transference improved the expression of renal transporters, such as Megalin and the sodium-glucose co-transporter-2 (SGLT2), and the structural restoration PTECs.

Recently, Kubat et al. [135] (Table 3) probed MT (mitochondria from MSCs injected into the cortex of right and left kidneys) in a model of kidney damage/renal injury induced with doxorubicin $(6 \mathrm{mg} / \mathrm{kg})$ in rats. MT promoted a reduction in proteinuria levels, the regeneration of tubules, and increased antioxidant enzyme levels, such as superoxide dismutase (SOD) and GPx. Besides, there was an evident reduction in apoptosis by increasing Bcl-2 levels, and a reduction in caspase-3 levels in injured renal cells, attributed to the effects of the replaced mitochondria. This is the first study showing the therapeutic effects of using MT in a nephrotoxicity model; however, the specific mechanisms by which 
mitochondria were internalized and the internalization mechanisms in this model were not evaluated.

Table 3. Recent studies showing the beneficial effects of mitochondrial transplantation in drug-induced pathologies in the kidney.

\begin{tabular}{|c|c|c|c|c|c|}
\hline $\begin{array}{l}\text { Mitochondrial } \\
\text { Source }\end{array}$ & Delivery Method & $\begin{array}{c}\text { Injury/Targeted } \\
\text { Organs }\end{array}$ & $\begin{array}{c}\text { Therapeutic } \\
\text { Outcome }\end{array}$ & $\begin{array}{c}\text { Mitochondrial } \\
\text { Concentration } \\
\text { Range }\end{array}$ & Reference \\
\hline BM-MSCs & $\begin{array}{c}\text { Directly injected } \\
\text { under the renal } \\
\text { capsule of the left } \\
\text { kidney }\end{array}$ & $\begin{array}{c}\text { Diabetic } \\
\text { nephropathy } \\
\text { induced with } \\
\text { streptozotocin } \\
\text { (55 mg } / \mathrm{kg}) \text { in male } \\
\text { Sprague-Dawley rats }\end{array}$ & $\begin{array}{l}\text { Improved cellular } \\
\text { morphology of PTECs and } \\
\text { the structure of the tubular } \\
\text { basement membrane and } \\
\text { cells with brush border. }\end{array}$ & $\begin{array}{c}\text { Mitochondria } \\
\text { obtained from } \\
1 \times 10^{6} \\
\text { BM-MSCs }\end{array}$ & Konari et al. [89] \\
\hline MSCs & $\begin{array}{c}\text { Transplanted } \\
\text { directly into the } \\
\text { cortex of right and } \\
\text { left kidneys }\end{array}$ & $\begin{array}{l}\text { Nephrotoxicity } \\
\text { induced with } \\
6 \mathrm{mg} / \mathrm{kg} \text { of } \\
\text { doxorubicin in Male } \\
\text { Sprague-Dawley rats }\end{array}$ & $\begin{array}{c}\text { cellular OS } \\
\text { Regeneration of tubular } \\
\text { cells } \\
\text { Reverted renal deficits, } \\
\text { Bcl-2 } \\
\text { caspase-3 levels }\end{array}$ & $\begin{array}{c}\text { Mitochondria } \\
\text { obtained from } \\
2 \times 10^{7} \text { cells } / \mathrm{mL}\end{array}$ & Kubat et al. [135] \\
\hline
\end{tabular}

Abbreviations: BM-MSCs: bone marrow mesenchymal stem cells, MSCs: mesenchymal stem cells, OS: oxidative stress, PTECs: proximal tubular epithelial cells, Bcl-2: B cell Lymphoma 2 family proteins.

Perico et al. [79] showed that the transplant of human umbilical cord mesenchymal stem cells (UC-MSCs) in mice with cisplatin induced AKI produced a multimodal paracrine action in which intra and intercellular pathways promoted reparative mechanisms mainly by preserving mitochondrial homeostasis and microtubule dependent organelle trafficking through the enhancement of Sirtuin-3 and 5'adenosine monophosphate activated protein kinase (AMPK) activation. Besides, there was tubular cell recovery by regulating mitochondrial biogenesis in the proximal tubule and preserving mitochondrial functional integrity by enhancing the peroxisome proliferator activated receptor gamma coactivator 1-alpha (PGC1- $\alpha$ ) expression, nicotinamide adenine dinucleotide (NAD+) biosynthesis, and Sirtuin-3 activity. The authors also found gene expression differences between resting cells and renal PTCs exposed to cisplatin and UC-MSCs, with a high recurrence of genes involved in mitochondrial metabolisms, such as amino acid catabolism, urea cycle, fatty acid metabolism, and ETS components. Although the authors did not study the specific role of mitochondrial transference, it can be noted that MSCs induced the reprogramming of damaged tubular cells mainly through the improvement of different mitochondrial pathways [79].

\section{(c) Heart}

Zhang et al. [136] reported that transplantation of human induced, pluripotent, stemcell derived MSCs (i.PSC-MSCs) (intramyocardial injection at four sites in the left ventricle) into a mouse model of doxorubicin induced cardiomyopathy attenuated left ventricular dilatation, myocardial damage and fibrosis, resulting in good mitochondrial retention in cardiomyocytes and the bioenergetic preservation of the heart tissue. The i.PSC-MSCs attenuated the doxorubicin induced cardiomyocyte damage mainly by increasing tunneling nanotubes formation and the TNF- $\alpha$ /nuclear factor kappa light chain enhancer of activated $B$ cells (NF- kB) signaling pathway and Miro-1.

Therefore, this study showed the protective effects of iPSC-MSCs against doxorubicininduced cardiomyopathy by mitochondrial transfer of iPSC-MSCs to damaged cardiomyocytes.

As shown in Section 3.4, some recent studies have attempted to perform the MT in drug induced pathologies in several organs. These exciting results emphasize the many benefits of transplanting respiratory-competent mitochondria to alleviate mitochondrial alterations, oxidative stress, and tissue injuries during drug-induced toxicity. 


\section{MT as a Possible Therapy against Cisplatin-Induced Cardiorenal Alterations}

In this review, we discuss if MT could have new possibilities in treating or complementing existing therapies to prevent the side effects produced by cisplatin, since some approximations with other nephrotoxins have already been made [135].

As mentioned, oxidative stress and mitochondrial dysfunction are pivotal contributors to renal and cardiac cell death during cisplatin toxicity [36]. Cisplatin primarily impairs respiratory function, and induces lipid peroxidation and mtDNA damage $[55,89]$. On the other hand, MT has shown beneficial results in several pathophysiological contexts $[36,137]$. However, MT is an emerging field that requires more detailed investigations for its potential use as a joint therapy against oxidative stress and mitochondrial dysfunction $[81,138]$ in the context of the use of chemotherapies.

Although many beneficial effects have been probed during mitochondrial therapy, this field has some limitations. For example, several diseases affect mitochondria in different tissues, because mtDNA mutations are expressed at different ratios in different tissues (heteroplasmy) [139]. Therefore, the source of mitochondria and previous genetic analysis of mtDNA will have to be carried out before transplantation [140]. Concerning this, Maeda et al. [124] established a novel technology to generate somatic mitochondrial DNA replaced cells (MirCs), combined with a temporal reduction in endogenous mtDNA and coincubation with exogenous isolated mitochondria. The results showed that mitochondrial disease patient derived fibroblasts regained respiratory function and showed lifespan extension, suggesting a possible application to treat maternal inherited mitochondrial diseases and improving the possibilities of using mitochondria from the same individual (autologous).

Several tissues are damaged during chemotherapeutic treatment, which decreases the viability of autologous transplantation, a type of transplant that has not been shown to induce immune responses $[108,141]$. Many studies have overcome the use of autologous mitochondria by using other sources, such as MSCs [89,121,135], UC-MSCs, and bone marrow-mesenchymal stem cells (BM-MSCs) [50]. Like stem cell based therapy [50,79,89], mitochondria obtained from stem cells have provided a powerful treatment to repair acute organ damage due to their regenerative capacity [50]. The transplantation of human bone marrow MSCs in cisplatin induced AKI has improved disease symptoms, decreased cisplatin nephrotoxicity in vitro and in vivo, and enhanced mice survival with AKI. Some effects were attributed to mitochondrial biogenesis and metabolic pathways [50,87]. Mitochondria derived from MSCs and transferred to T lymphocytes have been proved to drive T-regulatory cells (T-reg) phenotype activation through forkhead box P3 (FOXP3), interleukin 2 receptor subunit alpha (IL2RA), cytotoxic T-lymphocyte antigen 4 (CTLA4), and transforming growth factor-beta (TGF- $\beta 1$ ) [113], suggesting that mitochondria from MSCs could promote immune regulation by directing $\mathrm{T}$ cells to a regulatory phenotype. However, it has been shown that adult stem cells' metabolic functions and somatic cells are attenuated with aging [36].

Plasma derived mitochondria could also be valuable sources of mitochondria $[142,143]$. Sampling is less invasive than muscle or other tissues, suggesting that their study is essential to establish other alternatives of MT and their possible therapeutic effects. However, extracellular mitochondria are a recent finding, and there is much to discover before using them in functional studies because their increases have been postulated as markers of damage [128]. The recent discovery of mitochondria in blood might be a potential source of plasma MT, facilitating the obtention and extraction in less invasive manners [133].

It would be necessary to investigate the adverse effects of DAMPs present in isolated heterogeneous or allergenic mitochondria when several injections could be needed [108]. Solutions of isolated mitochondria could contain some damaged mitochondrial membrane fragments and genomes that may act as DAMPs, inducing innate immune activation in the cytosol and highlighting the care of technical procedures during isolation [124]. The leakage of mtDNA from the mitochondrial matrix is a ligand of Toll-like receptor 9 (TLR-9), which induces immune responses and cell injury through the stimulation of NF- $\mathrm{kB}[125,130]$. 
The study of mitochondria protection before the transplant could be performed, such as covering them in liposomes or transplantation microvesicles rich in mitochondria [144].

More studies could improve the mitochondrial drug delivery system that can transport therapeutic molecules to the mitochondria of the targeted diseases cells, which could help to facilitate the cellular specific uptake of the foreign mitochondria to the damaged cells. For example, the cell-penetrating peptide (Pep-1) has been shown to facilitate the cellular uptake of foreign mitochondria and improve the disturbances produced after peroxide induced oxidative stress [145]. On the other hand, Maeda et al. [125] reported using the transactivator of transcription dextran complexes (TAT-dextran) to enhance the cellular uptake of exogenous mitochondria cocultured with rat cardiomyocytes. TAT-dextran improved the protective effect of mitochondrial replenishment against oxidative stress and increased the level of cellular uptake, reduced apoptosis, and prevented the reduction of oxidative phosphorylation. These findings suggest that mitochondria could be directed with specific peptides to reduce unspecific internalization, which would be essential to overcoming mitochondria's unspecific loss in systemic transplantation, a more accessible form of transplantation.

The possibility of transplanting mitochondria into noncancerous cells damaged by cisplatin therapy is a challenge that depends on effective internalization strategies and the route of administration to the body. Therapies against the cytotoxic effects of cisplatin preferentially seek tissue preservation and aim to avoid possible interaction with chemotherapy at all costs. Preclinical studies should evaluate the potential interference of MT in the effectiveness of cisplatin therapy during cancer. There are some controversial studies about the different effects of the mitochondrial uptake in cancer cells, mainly due to the contradiction between the energetic requirements of the different types of cancer cells because some have a Warburg effect (aerobic glycolysis in cancer cells), and others depend mainly on oxidative phosphorylation (OXPHOS) [146].

It is known that there is a mutual interaction between neoplastic drugs and the tumor microenvironment [147]. Tumors are generally associated with nontumor cells through complex interactions that promote survival and chemoresistance [118]. The transfer of mitochondria between normal activated MSCs and the MSC cell line HS27a activated them after exposition to the ROS-inducing chemotherapy agents (cytarabine and daunorubicin) that activated HS27a cells were able to prevent therapy induced apoptosis and death due to a recovered OXPHOS metabolism. Mouse intact mitochondria from syngeneic mice were incorporated in B16 00 mouse melanoma cells (cells devoid of mtDNA), showing a normalization of their mitochondrial respiration. Interestingly, the decrease in critical mitochondrial complex I and complex II subunits abolished or retarded the ability of tumor formation [148], suggesting that these cells mainly depended on OXPHOS [146].

Elliot et al. [149] showed that transplantation of mitochondria, from untransformed mammary epithelial cell line (MCF-12A), into human cancer cells (MDA-MB-231, NCI/ADR-Res, and MCF-7) inhibited the proliferation of MCF-7 and NCI/ADR-Res positive cancer cells and reverted chemoresistance to doxorubicin, Abraxane and carboplatin. The last data suggest that MT could revert cancer cell metabolism. However, oppositely, Caicedo et al. [150] showed that the acquisition of mitochondria from MSCs by a cancer cell line (MDA-MB-232) (by MitoCeption) led to a remarkable increase in mtDNA concentration, oxidative phosphorylation, ATP production, and invasion and proliferation capacities for the MDA-MB-231 cancer cells, suggesting that the resource of the mitochondria plays an essential role in the phenotype that cancer cells acquire.

In vivo and in vitro experiments have shown that the cisplatin cytotoxic effect correlates with the mitochondria cellular density in the length of the intestinal epithelium and intestinal epithelial cells (IEC-6). The reduction in mitochondrial density prevented noncancer cells from dying from apoptosis or necrosis, suggesting that cells with a higher density of mitochondria seem to accumulate a large amount of cisplatin [49]. Just as we described before, drug induced liver, kidney and heart toxicity were notably ameliorated after direct and systemic transplant of mitochondria in the respective models so, we could 
not assert that a more significant number of mitochondria is toxic during treatment with cisplatin, since this agent produces very similar effects to doxorubicin, such as oxidative stress and ROS [151], which was used in the models described by Kubat et al. [135] (see Table 3) and Zhang et al. [136].

Finally, Boukelmoune et al. [101] reported that MSCs transferred healthy mitochondria to NSCs treated with cisplatin in vitro. Exogenous mitochondria were able to improve mitochondrial membrane potential in NSCs, as well as survival. Thus, the incorporation of mitochondria in cells could exert other important mechanisms independent of mitochondrial density and cisplatin response. MT is a burgeoning field that could be applicable for treating many nephrotoxic and cardiotoxic injuries in which conventional therapies have been unsuccessful, but there is a lot to discover in the new therapeutic approaches. Therefore, developing new models for studying MT in organs with a high density of mitochondria, such as the heart or the kidney, during cisplatin treated cancer is a field that needs to be further explored.

\section{Concluding Remarks and Future Directions}

The current review presents several studies highlighting ROS production and mitochondrial dysfunction as the principal side effects during cisplatin therapy in the heart and the kidney. Cisplatin is a platinum compound that is still used worldwide for the treatment of several cancers. Clinical attempts to ameliorate cisplatin-induced cardiac toxicity have also met very little success. Therefore, it has become imperative to limit these toxicities associated with cisplatin treatment. Treatments of cisplatin induced renal and cardiac toxicities remain significant challenges, despite several clinical interventions. Although we presented some studies addressing how transplanted mitochondria could rescue respiratory function and other disturbances in the damaged mitochondria, there are still different questions that must be carefully addressed during treatment experimentation. Continued research in the mechanisms of adverse drug side effects is imperative to our advancement in continuing to predict, treat, and ultimately prevent serious adverse events in cisplatin treatment and even other chemotherapeutics that induce renal and cardiac alterations. The effects of MT go beyond alleviating oxidative stress, since replenishing with healthy mitochondria restores mtDNA and other metabolic functions, such as the tricarboxylic cycle, urea cycle, nucleotide synthesis, calcium homeostasis and proliferation.

Author Contributions: Conceptualization, I.A.-M. and J.P.-C.; investigation, I.A.-M., O.E.A.-T. and A.P.J.-U.; writing—original draft preparation, I.A.-M.; writing—review and editing, I.A.-M., E.Y.H.-C., A.P.J.-U., L.G.S.-L., O.E.A.-T., J.B.-C., E.T. and J.P.-C.; visualization, E.Y.H.-C.; supervision, J.P.-C. and L.G.S.-L.; funding acquisition, J.P.-C. All authors have read and agreed to the published version of the manuscript.

Funding: This research was funded by Consejo Nacional de Ciencia y Tecnología (CONACYT) México, Grants Numbers A1-S-7495; by Programa de Apoyo a Proyectos de Investigación e Innovación Tecnológica (PAPIT), Grant Numbers IN202219 and IN200922 of the Universidad Nacional Autónoma de México (UNAM); by Programa de Apoyo a la Investigación y el Posgrado (PAIP), Grant Number 5000-9105.

Acknowledgments: I.A.-M. and E.Y.H.-C. are doctoral students from Programa de Doctorado en Ciencias Biológicas from Universidad Nacional Autónoma de México (UNAM) and E.Y.H.-C. received fellowship 779741 from CONACyT.

Conflicts of Interest: The authors declare no conflict of interest.

\section{References}

1. Hoste, E.A.J.; Kellum, J.A.; Selby, N.M.; Zarbock, A.; Palevsky, P.M.; Bagshaw, S.M.; Goldstein, S.L.; Cerdá, J.; Chawla, L.S. Global Epidemiology and Outcomes of Acute Kidney Injury. Nat. Rev. Nephrol. 2018, 14, 607-625. [CrossRef] [PubMed]

2. Ikizler, T.A.; Parikh, C.R.; Himmelfarb, J.; Chinchilli, V.M.; Liu, K.D.; Coca, S.G.; Garg, A.X.; Hsu, C.; Siew, E.D.; Wurfel, M.M.; et al. A Prospective Cohort Study of Acute Kidney Injury and Kidney Outcomes, Cardiovascular Events, and Death. Kidney Int. 2021, 99, 456-465. [CrossRef] [PubMed] 
3. Kane-Gill, S.L.; Goldstein, S.L. Drug-Induced Acute Kidney Injury. Crit. Care Clin. 2015, 31, 675-684. [CrossRef]

4. Mehta, R.L.; Pascual, M.T.; Soroko, S.; Savage, B.R.; Himmelfarb, J.; Ikizler, T.A.; Paganini, E.P.; Chertow, G.M. Spectrum of Acute Renal Failure in the Intensive Care Unit: The PICARD Experience. Kidney Int. 2004, 66, 1613-1621. [CrossRef]

5. $\quad$ Faught, L.N.; Greff, M.J.E.; Rieder, M.J.; Koren, G. Drug-Induced Acute Kidney Injury in Children: Drug-Induced AKI in Children. Br. J. Clin. Pharmacol. 2015, 80, 901-909. [CrossRef]

6. Uchino, S. The Epidemiology of Acute Renal Failure in the World. Curr. Opin. Crit. Care 2006, 12, 538-543. [CrossRef] [PubMed]

7. Sales, G.T.M.; Foresto, R.D. Drug-Induced Nephrotoxicity. Rev. Assoc. Méd. Bras. 2020, 66 (Suppl. S1), s82-s90. [CrossRef] [PubMed]

8. Wu, W.; Fu, Y.; Liu, Z.; Shu, S.; Wang, Y.; Tang, C.; Cai, J.; Dong, Z. NAM Protects against Cisplatin-Induced Acute Kidney Injury by Suppressing the PARP1/P53 Pathway. Toxicol. Appl. Pharmacol. 2021, 418, 115492. [CrossRef]

9. Kwiatkowska, E.; Domański, L.; Dziedziejko, V.; Kajdy, A.; Stefańska, K.; Kwiatkowski, S. The Mechanism of Drug Nephrotoxicity and the Methods for Preventing Kidney Damage. Int. J. Mol. Sci. 2021, 22, 6109. [CrossRef]

10. Zhou, J.; Kang, Y.; Chen, L.; Wang, H.; Liu, J.; Zeng, S.; Yu, L. The Drug-Resistance Mechanisms of Five Platinum-Based Antitumor Agents. Front. Pharmacol. 2020, 11, 343. [CrossRef]

11. Oun, R.; Moussa, Y.E.; Wheate, N.J. The Side Effects of Platinum-Based Chemotherapy Drugs: A Review for Chemists. Dalton Trans. 2018, 47, 6645-6653. [CrossRef] [PubMed]

12. Buechel, M.; Herzog, T.J.; Westin, S.N.; Coleman, R.L.; Monk, B.J.; Moore, K.N. Treatment of Patients with Recurrent Epithelial Ovarian Cancer for Whom Platinum Is Still an Option. Ann. Oncol. 2019, 30, 721-732. [CrossRef]

13. Liu, Y.L.; Zhou, Q.; Iasonos, A.; Emengo, V.N.; Friedman, C.; Konner, J.A.; O'Cearbhaill, R.E.; Aghajanian, C.; Zamarin, D. Subsequent Therapies and Survival after Immunotherapy in Recurrent Ovarian Cancer. Gynecol. Oncol. 2019,155, 51-57. [CrossRef] [PubMed]

14. Wang, W.; Wu, M.; Wu, D.; Wang, L.; Li, H.; Lin, Z.; Li, J. Calculating the Dose of Cisplatin That Is Actually Utilized in Hyperthermic Intraperitoneal Chemotherapy among Ovarian Cancer Patients. J. Ovarian Res. 2021, 14, 9. [CrossRef]

15. Tsao, L.R.; Young, F.D.; Otani, I.M.; Castells, M.C. Hypersensitivity Reactions to Platinum Agents and Taxanes. Clin. Rev. Allergy Immunol. 2021, 1-17. (In Press) [CrossRef]

16. Funakoshi, Y.; Fujiwara, Y.; Kiyota, N.; Mukohara, T.; Shimada, T.; Toyoda, M.; Imamura, Y.; Chayahara, N.; Tomioka, H.; Umezu, M.; et al. Validity of New Methods to Evaluate Renal Function in Cancer Patients Treated with Cisplatin. Cancer Chemother. Pharmacol. 2016, 77, 281-288. [CrossRef]

17. Tixier, F.; Ranchon, F.; Iltis, A.; Vantard, N.; Schwiertz, V.; Bachy, E.; Bouafia-Sauvy, F.; Sarkozy, C.; Tournamille, J.F.; Gyan, E.; et al. Comparative Toxicities of 3 Platinum-Containing Chemotherapy Regimens in Relapsed/Refractory Lymphoma Patients: Platinum-Containing Chemotherapy Regimens. Hematol. Oncol. 2017, 35, 584-590. [CrossRef]

18. Sato, K.; Watanabe, S.; Ohtsubo, A.; Shoji, S.; Ishikawa, D.; Tanaka, T.; Nozaki, K.; Kondo, R.; Okajima, M.; Miura, S.; et al. Nephrotoxicity of Cisplatin Combination Chemotherapy in Thoracic Malignancy Patients with CKD Risk Factors. BMC Cancer 2016, 16, 222. [CrossRef]

19. Latcha, S.; Jaimes, E.A.; Patil, S.; Glezerman, I.G.; Mehta, S.; Flombaum, C.D. Long-Term Renal Outcomes after Cisplatin Treatment. Clin. J. Am. Soc. Nephrol. 2016, 11, 1173-1179. [CrossRef]

20. Shi, M.; McMillan, K.L.; Wu, J.; Gillings, N.; Flores, B.; Moe, O.W.; Hu, M.C. Cisplatin Nephrotoxicity as a Model of Chronic Kidney Disease. Lab. Investig. 2018, 98, 1105-1121. [CrossRef] [PubMed]

21. Małyszko, J.; Kozłowska, K.; Kozłowski, L.; Małyszko, J. Nephrotoxicity of Anticancer Treatment. Nephrol. Dial. Transplant. 2016, 32, 924-936. [CrossRef]

22. Pabla, N.; Dong, Z. Cisplatin Nephrotoxicity: Mechanisms and Renoprotective Strategies. Kidney Int. 2008, $73,994-1007$. [CrossRef]

23. Gudsoorkar, P.S.; Thakar, C.V. Acute Kidney Injury, Heart Failure, and Health Outcomes. Cardiol. Clin. 2019, 37, 297-305. [CrossRef]

24. Gómez-Sierra, T.; Eugenio-Pérez, D.; Sánchez-Chinchillas, A.; Pedraza-Chaverri, J. Role of Food-Derived Antioxidants against Cisplatin Induced-Nephrotoxicity. Food Chem. Toxicol. 2018, 120, 230-242. [CrossRef] [PubMed]

25. Perazella, M.A. Onco-Nephrology: Renal Toxicities of Chemotherapeutic Agents. Clin. J. Am. Soc. Nephrol. 2012, 7, $1713-1721$. [CrossRef]

26. McSweeney, K.R.; Gadanec, L.K.; Qaradakhi, T.; Ali, B.A.; Zulli, A.; Apostolopoulos, V. Mechanisms of Cisplatin-Induced Acute Kidney Injury: Pathological Mechanisms, Pharmacological Interventions, and Genetic Mitigations. Cancers 2021, $13,1572$. [CrossRef]

27. Kramann, R.; Kusaba, T.; Humphreys, B.D. Who Regenerates the Kidney Tubule? Nephrol. Dial. Transplant. 2015, 30, 903-910. [CrossRef]

28. Oh, G.-S.; Kim, H.-J.; Shen, A.; Lee, S.B.; Khadka, D.; Pandit, A.; So, H.-S. Cisplatin-Induced Kidney Dysfunction and Perspectives on Improving Treatment Strategies. Electrolytes Blood Press. 2014, 12, 55. [CrossRef]

29. Rangaswami, J.; Bhalla, V.; Blair, J.E.A.; Chang, T.I.; Costa, S.; Lentine, K.L.; Lerma, E.V.; Mezue, K.; Molitch, M.; Mullens, W.; et al. Cardiorenal Syndrome: Classification, Pathophysiology, Diagnosis, and Treatment Strategies: A Scientific Statement From the American Heart Association. Circulation 2019, 139, e840-e878. [CrossRef] [PubMed] 
30. McCullough, P.A. Cardiorenal Syndromes: Pathophysiology to Prevention. Int. J. Nephrol. 2011, 2011, 762590. [CrossRef] [PubMed]

31. Rubattu, S.; Mennuni, S.; Testa, M.; Mennuni, M.; Pierelli, G.; Pagliaro, B.; Gabriele, E.; Coluccia, R.; Autore, C.; Volpe, M. Pathogenesis of Chronic Cardiorenal Syndrome: Is There a Role for Oxidative Stress? Int. J. Mol. Sci. 2013, 14, 23011-23032. [CrossRef] [PubMed]

32. Soranno, D.E.; Kirkbride-Romeo, L.; Wennersten, S.A.; Ding, K.; Cavasin, M.A.; Baker, P.; Altmann, C.; Bagchi, R.A.; Haefner, K.R.; Steinkühler, C.; et al. Acute Kidney Injury Results in Long-Term Diastolic Dysfunction That Is Prevented by Histone Deacetylase Inhibition. JACC Basic Transl. Sci. 2021, 6, 119-133. [CrossRef] [PubMed]

33. Patanè, S. Cardiotoxicity: Cisplatin and Long-Term Cancer Survivors. Int. J. Cardiol. 2014, 175, 201-202. [CrossRef]

34. El-Hawwary, A.A.; Omar, N.M. The Influence of Ginger Administration on Cisplatin-Induced Cardiotoxicity in Rat: Light and Electron Microscopic Study. Acta Histochem. 2019, 121, 553-562. [CrossRef]

35. Hanchate, L.P. Cisplatin Induced Acute Myocardial Infarction and Dyslipidemia. J. Clin. Diagn. Res. 2017, 11, OD05-OD07. [CrossRef]

36. Dugbartey, G.J.; Peppone, L.J.; de Graaf, I.A.M. An Integrative View of Cisplatin-Induced Renal and Cardiac Toxicities: Molecular Mechanisms, Current Treatment Challenges and Potential Protective Measures. Toxicology 2016, 371, 58-66. [CrossRef] [PubMed]

37. Bjerring, A.W.; Fosså, S.D.; Haugnes, H.S.; Nome, R.; Stokke, T.M.; Haugaa, K.H.; Kiserud, C.E.; Edvardsen, T.; Sarvari, S.I. The Cardiac Impact of Cisplatin-Based Chemotherapy in Survivors of Testicular Cancer: A 30-Year Follow-Up. Eur. Heart J.-Cardiovasc. Imaging 2021, 22, 443-450. [CrossRef]

38. Steingart, R. Mechanisms of Late Cardiovascular Toxicity from Cancer Chemotherapy. J. Clin. Oncol. 2005, 23, 9051-9052. [CrossRef]

39. Steingart, R.M.; Yadav, N.; Manrique, C.; Carver, J.R.; Liu, J. Cancer Survivorship: Cardiotoxic Therapy in the Adult Cancer Patient; Cardiac Outcomes With Recommendations for Patient Management. Semin. Oncol. 2013, 40, 690-708. [CrossRef]

40. Ibrahim, M.A.; Bakhaat, G.A.; Tammam, H.G.; Mohamed, R.M.; El-Naggar, S.A. Cardioprotective Effect of Green Tea Extract and Vitamin E on Cisplatin-Induced Cardiotoxicity in Mice: Toxicological, Histological and Immunohistochemical Studies. Biomed. Pharmacother. 2019, 113, 108731. [CrossRef]

41. Cui, Y.; Li, C.; Zeng, C.; Li, J.; Zhu, Z.; Chen, W.; Huang, A.; Qi, X. Tongmai Yangxin Pills Anti-Oxidative Stress Alleviates Cisplatin-Induced Cardiotoxicity: Network Pharmacology Analysis and Experimental Evidence. Biomed. Pharmacother. 2018, 108, 1081-1089. [CrossRef] [PubMed]

42. Bahadır, A. Protective Effects of Curcumin and Beta-Carotene on Cisplatin-Induced Cardiotoxicity: An Experimental Rat Model. Anatol. J. Cardiol. 2018, 19, 213-221. [CrossRef]

43. Saleh, D.O.; Mansour, D.F.; Mostafa, R.E. Rosuvastatin and Simvastatin Attenuate Cisplatin-Induced Cardiotoxicity via Disruption of Endoplasmic Reticulum Stress-Mediated Apoptotic Death in Rats: Targeting ER-Chaperone GRP78 and Calpain-1 Pathways. Toxicol. Rep. 2020, 7, 1178-1186. [CrossRef] [PubMed]

44. Chirino, Y.I.; Pedraza-Chaverri, J. Role of Oxidative and Nitrosative Stress in Cisplatin-Induced Nephrotoxicity. Exp. Toxicol. Pathol. 2009, 61, 223-242. [CrossRef]

45. Mapuskar, K.A.; Wen, H.; Holanda, D.G.; Rastogi, P.; Steinbach, E.; Han, R.; Coleman, M.C.; Attanasio, M.; Riley, D.P.; Spitz, D.R.; et al. Persistent Increase in Mitochondrial Superoxide Mediates Cisplatin-Induced Chronic Kidney Disease. Redox Biol. 2019, 20 98-106. [CrossRef] [PubMed]

46. Marullo, R.; Werner, E.; Degtyareva, N.; Moore, B.; Altavilla, G.; Ramalingam, S.S.; Doetsch, P.W. Cisplatin Induces a Mitochondrial-ROS Response That Contributes to Cytotoxicity Depending on Mitochondrial Redox Status and Bioenergetic Functions. PLoS ONE 2013, 8, e81162. [CrossRef]

47. Miller, R.P.; Tadagavadi, R.K.; Ramesh, G.; Reeves, W.B. Mechanisms of Cisplatin Nephrotoxicity. Toxins 2010, 2, 2490-2518. [CrossRef]

48. Mandic, A.; Hansson, J.; Linder, S.; Shoshan, M.C. Cisplatin Induces Endoplasmic Reticulum Stress and Nucleus-Independent Apoptotic Signaling. J. Biol. Chem. 2003, 278, 9100-9106. [CrossRef]

49. Qian, W.; Nishikawa, M.; Haque, A.M.; Hirose, M.; Mashimo, M.; Sato, E.; Inoue, M. Mitochondrial Density Determines the Cellular Sensitivity to Cisplatin-Induced Cell Death. Am. J. Physiol.-Cell Physiol. 2005, 289, C1466-C1475. [CrossRef] [PubMed]

50. Moghadasali, R.; Azarnia, M.; Hajinasrollah, M.; Arghani, H.; Nassiri, S.M.; Molazem, M.; Vosough, A.; Mohitmafi, S.; Najarasl, M.; Ajdari, Z.; et al. Intra-Renal Arterial Injection of Autologous Bone Marrow Mesenchymal Stromal Cells Ameliorates Cisplatin-Induced Acute Kidney Injury in a Rhesus Macaque Mulatta Monkey Model. Cytotherapy 2014, 16, 734-749. [CrossRef]

51. Harrach, S.; Ciarimboli, G. Role of Transporters in the Distribution of Platinum-Based Drugs. Front. Pharmacol. 2015, 6, 85. [CrossRef]

52. Freitas-Lima, L.C.; Budu, A.; Arruda, A.C.; Perilhão, M.S.; Barrera-Chimal, J.; Araujo, R.C.; Estrela, G.R. PPAR- $\alpha$ Deletion Attenuates Cisplatin Nephrotoxicity by Modulating Renal Organic Transporters MATE-1 and OCT-2. Int. J. Mol. Sci. 2020, 21, 7416. [CrossRef]

53. Townsend, D.M.; Deng, M.; Zhang, L.; Lapus, M.G.; Hanigan, M.H. Metabolism of Cisplatin to a Nephrotoxin in Proximal Tubule Cells. J. Am. Soc. Nephrol. 2003, 14, 1-10. [CrossRef]

54. Townsend, D.M.; Tew, K.D.; He, L.; King, J.B.; Hanigan, M.H. Role of Glutathione S-Transferase Pi in Cisplatin-Induced Nephrotoxicity. Biomed. Pharmacother. 2009, 63, 79-85. [CrossRef] [PubMed] 
55. Ichinomiya, M.; Shimada, A.; Ohta, N.; Inouchi, E.; Ogihara, K.; Naya, Y.; Nagane, M.; Morita, T.; Satoh, M. Demonstration of Mitochondrial Damage and Mitophagy in Cisplatin-Mediated Nephrotoxicity. Tohoku J. Exp. Med. 2018, 246, 1-8. [CrossRef] [PubMed]

56. Ortega-Domínguez, B.; Aparicio-Trejo, O.E.; García-Arroyo, F.E.; León-Contreras, J.C.; Tapia, E.; Molina-Jijón, E.; HernándezPando, R.; Sánchez-Lozada, L.G.; Barrera-Oviedo, D.; Pedraza-Chaverri, J. Curcumin Prevents Cisplatin-Induced Renal Alterations in Mitochondrial Bioenergetics and Dynamic. Food Chem. Toxicol. 2017, 107, 373-385. [CrossRef]

57. Yan, M.; Tang, C.; Ma, Z.; Huang, S.; Dong, Z. DNA Damage Response in Nephrotoxic and Ischemic Kidney Injury. Toxicol. Appl. Pharmacol. 2016, 313, 104-108. [CrossRef]

58. Bernal-Barquero, C.E.; Vazquez-Zapien, G.J.; Mata-Miranda, M.M. Review of Alterations in Gene Expression and Apoptotic Pathways Caused in Nephrotoxicity Induced by Cisplatin. Nefrología 2019, 39, 362-371. [CrossRef] [PubMed]

59. Ishimoto, Y.; Inagi, R. Mitochondria: A Therapeutic Target in Acute Kidney Injury. Nephrol. Dial. Transplant. 2016, 31, 1062-1069. [CrossRef]

60. Wang, Y.; Tang, C.; Cai, J.; Chen, G.; Zhang, D.; Zhang, Z.; Dong, Z. PINK1/Parkin-Mediated Mitophagy Is Activated in Cisplatin Nephrotoxicity to Protect against Kidney Injury. Cell Death Dis. 2018, 9, 1113. [CrossRef]

61. Banci, L.; Bertini, I.; Ciofi-Baffoni, S.; Hadjiloi, T.; Martinelli, M.; Palumaa, P. Mitochondrial Copper(I) Transfer from Cox17 to Sco1 Is Coupled to Electron Transfer. Proc. Natl. Acad. Sci. USA 2008, 105, 6803-6808. [CrossRef]

62. Ong, J.X.; Le, H.V.; Lee, V.E.Y.; Ang, W.H. A Cisplatin-Selective Fluorescent Probe for Real-Time Monitoring of Mitochondrial Platinum Accumulation in Living Cells. Angew. Chem. Int. Ed. 2021, 60, 9264-9269. [CrossRef]

63. Meyer, J.N.; Hartman, J.H.; Mello, D.F. Mitochondrial Toxicity. Toxicol. Sci. 2018, 162, 15-23. [CrossRef] [PubMed]

64. dos Santos, N.A.G.; Carvalho Rodrigues, M.A.; Martins, N.M.; dos Santos, A.C. Cisplatin-Induced Nephrotoxicity and Targets of Nephroprotection: An Update. Arch. Toxicol. 2012, 86, 1233-1250. [CrossRef]

65. Ueki, M.; Ueno, M.; Morishita, J.; Maekawa, N. Curcumin Ameliorates Cisplatin-Induced Nephrotoxicity by Inhibiting Renal Inflammation in Mice. J. Biosci. Bioeng. 2013, 115, 547-551. [CrossRef]

66. Demkow, U.; Stelmaszczyk-Emmel, A. Cardiotoxicity of Cisplatin-Based Chemotherapy in Advanced Non-Small Cell Lung Cancer Patients. Respir. Physiol. Neurobiol. 2013, 187, 64-67. [CrossRef] [PubMed]

67. van der Bliek, A.M.; Sedensky, M.M.; Morgan, P.G. Cell Biology of the Mitochondrion. Genetics 2017, 207, 843-871. [CrossRef] [PubMed]

68. Barry, H.; John, M.C.G. Free Radical in Biology and Medicine, 5th ed.; Oxford University Press: Oxford, UK, 2015.

69. Liguori, I.; Russo, G.; Curcio, F.; Bulli, G.; Aran, L.; Della-Morte, D.; Gargiulo, G.; Testa, G.; Cacciatore, F.; Bonaduce, D.; et al. Oxidative Stress, Aging, and Diseases. Clin. Interv. Aging 2018, 13, 757-772. [CrossRef]

70. Gyurászová, M.; Gurecká, R.; Bábíčková, J.; Tóthová, L'. Oxidative Stress in the Pathophysiology of Kidney Disease: Implications for Noninvasive Monitoring and Identification of Biomarkers. Oxid. Med. Cell. Longev. 2020, 2020, 5478708. [CrossRef] [PubMed]

71. Briones-Herrera, A.; Avila-Rojas, S.H.; Aparicio-Trejo, O.E.; Cristóbal, M.; León-Contreras, J.C.; Hernández-Pando, R.; Pinzón, E.; Pedraza-Chaverri, J.; Sánchez-Lozada, L.G.; Tapia, E. Sulforaphane Prevents Maleic Acid-Induced Nephropathy by Modulating Renal Hemodynamics, Mitochondrial Bioenergetics and Oxidative Stress. Food Chem. Toxicol. 2018, 115, 185-197. [CrossRef]

72. Pan, H.; Chen, J.; Shen, K.; Wang, X.; Wang, P.; Fu, G.; Meng, H.; Wang, Y.; Jin, B. Mitochondrial Modulation by Epigallocatechin 3-Gallate Ameliorates Cisplatin Induced Renal Injury through Decreasing Oxidative/Nitrative Stress, Inflammation and NF-KB in Mice. PLoS ONE 2015, 10, e0124775. [CrossRef]

73. Zhang, Y.; Chen, Y.; Li, B.; Ding, P.; Jin, D.; Hou, S.; Cai, X.; Sheng, X. The Effect of Monotropein on Alleviating Cisplatin-Induced Acute Kidney Injury by Inhibiting Oxidative Damage, Inflammation and Apoptosis. Biomed. Pharmacother. 2020, $129,110408$. [CrossRef]

74. Quinlan, C.L.; Perevoshchikova, I.V.; Hey-Mogensen, M.; Orr, A.L.; Brand, M.D. Sites of Reactive Oxygen Species Generation by Mitochondria Oxidizing Different Substrates. Redox Biol. 2013, 1, 304-312. [CrossRef]

75. Quinlan, C.L.; Treberg, J.R.; Perevoshchikova, I.V.; Orr, A.L.; Brand, M.D. Native Rates of Superoxide Production from Multiple Sites in Isolated Mitochondria Measured Using Endogenous Reporters. Free Radic. Biol. Med. 2012, 53, 1807-1817. [CrossRef] [PubMed]

76. Shanmugasundaram, K.; Nayak, B.K.; Friedrichs, W.E.; Kaushik, D.; Rodriguez, R.; Block, K. NOX4 Functions as a Mitochondrial Energetic Sensor Coupling Cancer Metabolic Reprogramming to Drug Resistance. Nat. Commun. 2017, 8, 997. [CrossRef]

77. Reyes-Fermín, L.M.; Avila-Rojas, S.H.; Aparicio-Trejo, O.E.; Tapia, E.; Rivero, I.; Pedraza-Chaverri, J. The Protective Effect of Alpha-Mangostin against Cisplatin-Induced Cell Death in LLC-PK1 Cells Is Associated to Mitochondrial Function Preservation. Antioxidants 2019, 8, 133. [CrossRef]

78. Zhu, L.; Yuan, Y.; Yuan, L.; Li, L.; Liu, F.; Liu, J.; Chen, Y.; Lu, Y.; Cheng, J. Activation of TFEB-Mediated Autophagy by Trehalose Attenuates Mitochondrial Dysfunction in Cisplatin-Induced Acute Kidney Injury. Theranostics 2020, 10, 5829-5844. [CrossRef] [PubMed]

79. Perico, L.; Morigi, M.; Rota, C.; Breno, M.; Mele, C.; Noris, M.; Introna, M.; Capelli, C.; Longaretti, L.; Rottoli, D.; et al. Human Mesenchymal Stromal Cells Transplanted into Mice Stimulate Renal Tubular Cells and Enhance Mitochondrial Function. Nat. Commun. 2017, 8, 983. [CrossRef]

80. Javadov, S.; Jang, S.; Agostini, B. Crosstalk between Mitogen-Activated Protein Kinases and Mitochondria in Cardiac Diseases: Therapeutic Perspectives. Pharmacol. Ther. 2014, 144, 202-225. [CrossRef] [PubMed] 
81. Gollihue, J.L.; Rabchevsky, A.G. Prospects for Therapeutic Mitochondrial Transplantation. Mitochondrion 2017, 35, 70-79. [CrossRef]

82. Meng, X.-M.; Ren, G.-L.; Gao, L.; Yang, Q.; Li, H.-D.; Wu, W.-F.; Huang, C.; Zhang, L.; Lv, X.; Li, J. NADPH Oxidase 4 Promotes Cisplatin-Induced Acute Kidney Injury via ROS-Mediated Programmed Cell Death and Inflammation. Lab. Investig. 2018, 98, 63-78. [CrossRef] [PubMed]

83. Wang, J.-N.; Yang, Q.; Yang, C.; Cai, Y.-T.; Xing, T.; Gao, L.; Wang, F.; Chen, X.; Liu, X.-Q.; He, X.-Y.; et al. Smad3 Promotes AKI Sensitivity in Diabetic Mice via Interaction with P53 and Induction of NOX4-Dependent ROS Production. Redox Biol. 2020, 32, 101479. [CrossRef]

84. El-Awady, E.-S.E.; Moustafa, Y.M.; Abo-Elmatty, D.M.; Radwan, A. Cisplatin-Induced Cardiotoxicity: Mechanisms and Cardioprotective Strategies. Eur. J. Pharmacol. 2011, 650, 335-341. [CrossRef] [PubMed]

85. Yang, Y.; Meng, L.; Wu, S.; Li, Y.; Zhong, Y.; Xu, F.; Zhou, X.; Li, G.; Xu, G.; Peng, K. LIGHT Deficiency Aggravates CisplatinInduced Acute Kidney Injury by Upregulating Mitochondrial Apoptosis. Int. Immunopharmacol. 2020, 89, 106999. [CrossRef] [PubMed]

86. Achkar, I.W.; Abdulrahman, N.; Al-Sulaiti, H.; Joseph, J.M.; Uddin, S.; Mraiche, F. Cisplatin Based Therapy: The Role of the Mitogen Activated Protein Kinase Signaling Pathway. J. Transl. Med. 2018, 16, 96. [CrossRef] [PubMed]

87. Jabbari, H.; Roushandeh, A.M.; Rostami, M.K.; Razavi-Toosi, M.T.; Shokrgozar, M.A.; Jahanian-Najafabadi, A.; Kuwahara, Y.; Roudkenar, M.H. Mitochondrial Transplantation Ameliorates Ischemia/Reperfusion-Induced Kidney Injury in Rat. Biochim. Biophys. Acta BBA-Mol. Basis Dis. 2020, 1866, 165809. [CrossRef] [PubMed]

88. Yang, C.; Kaushal, V.; Shah, S.V.; Kaushal, G.P. Autophagy Is Associated with Apoptosis in Cisplatin Injury to Renal Tubular Epithelial Cells. Am. J. Physiol.-Ren. Physiol. 2008, 294, F777-F787. [CrossRef] [PubMed]

89. Konari, N.; Nagaishi, K.; Kikuchi, S.; Fujimiya, M. Mitochondria Transfer from Mesenchymal Stem Cells Structurally and Functionally Repairs Renal Proximal Tubular Epithelial Cells in Diabetic Nephropathy in Vivo. Sci. Rep. 2019, 9, 5184. [CrossRef]

90. Luan, Z.; Wei, Y.; Huo, X.; Sun, X.; Zhang, C.; Ming, W.; Luo, Z.; Du, C.; Li, Y.; Xu, H.; et al. Pregnane X Receptor (PXR) Protects against Cisplatin-Induced Acute Kidney Injury in Mice. Biochim. Biophys. Acta BBA-Mol. Basis Dis. 2021, 1867, 165996. [CrossRef] [PubMed]

91. McCully, J.D.; Levitsky, S.; Nido, P.J.; Cowan, D.B. Mitochondrial Transplantation for Therapeutic Use. Clin. Transl. Med. 2016, 5, 16. [CrossRef]

92. Roushandeh, A.M.; Kuwahara, Y.; Roudkenar, M.H. Mitochondrial Transplantation as a Potential and Novel Master Key for Treatment of Various Incurable Diseases. Cytotechnology 2019, 71, 647-663. [CrossRef]

93. Mietsch, M.; Hinkel, R. “Empowering" Cardiac Cells via Stem Cell Derived Mitochondrial Transplantation- Does Age Matter? Int. J. Mol. Sci. 2021, 22, 1824. [CrossRef] [PubMed]

94. Sabbah, H.N. Targeting the Mitochondria in Heart Failure. JACC Basic Transl. Sci. 2020, 5, 88-106. [CrossRef]

95. Paliwal, S.; Chaudhuri, R.; Agrawal, A.; Mohanty, S. Regenerative Abilities of Mesenchymal Stem Cells through Mitochondrial Transfer. J. Biomed. Sci. 2018, 25, 31. [CrossRef] [PubMed]

96. Stanley, W.C.; Recchia, F.A.; Lopaschuk, G.D. Myocardial Substrate Metabolism in the Normal and Failing Heart. Physiol. Rev. 2005, 85, 1093-1129. [CrossRef]

97. Shaker, M.E.; Shaaban, A.A.; El-Shafey, M.M.; El-Mesery, M.E. The Selective C-Met Inhibitor Capmatinib Offsets CisplatinNephrotoxicity and Doxorubicin-Cardiotoxicity and Improves Their Anticancer Efficacies. Toxicol. Appl. Pharmacol. 2020, 398, 115018. [CrossRef]

98. Kanzaki, Y.; Terasaki, F.; Okabe, M.; Otsuka, K.; Katashima, T.; Fujita, S.; Ito, T.; Kitaura, Y. Giant Mitochondria in the Myocardium of a Patient With Mitochondrial Cardiomyopathy: Transmission and 3-Dimensional Scanning Electron Microscopy. Circulation 2010, 121, 831-832. [CrossRef]

99. Huang, X.; Sun, L.; Ji, S.; Zhao, T.; Zhang, W.; Xu, J.; Zhang, J.; Wang, Y.; Wang, X.; Franzini-Armstrong, C.; et al. Kissing and Nanotunneling Mediate Intermitochondrial Communication in the Heart. Proc. Natl. Acad. Sci. USA 2013, 110, $2846-2851$. [CrossRef]

100. Gollihue, J.L.; Patel, S.P.; Mashburn, C.; Eldahan, K.C.; Sullivan, P.G.; Rabchevsky, A.G. Optimization of Mitochondrial Isolation Techniques for Intraspinal Transplantation Procedures. J. Neurosci. Methods 2017, 287, 1-12. [CrossRef] [PubMed]

101. Boukelmoune, N.; Chiu, G.S.; Kavelaars, A.; Heijnen, C.J. Mitochondrial Transfer from Mesenchymal Stem Cells to Neural Stem Cells Protects against the Neurotoxic Effects of Cisplatin. Acta Neuropathol. Commun. 2018, 6, 139. [CrossRef]

102. Lynch, E.D.; Gu, R.; Pierce, C.; Kil, J. Reduction of Acute Cisplatin Ototoxicity and Nephrotoxicity in Rats by Oral Administration of Allopurinol and Ebselen. Hear. Res. 2005, 201, 81-89. [CrossRef] [PubMed]

103. Valentovic, M.A.; Ball, J.G.; Mike Brown, J.; Terneus, M.V.; McQuade, E.; Van Meter, S.; Hedrick, H.M.; Roy, A.A.; Williams, T. Resveratrol Attenuates Cisplatin Renal Cortical Cytotoxicity by Modifying Oxidative Stress. Toxicol. In Vitro 2014, $28,248-257$. [CrossRef] [PubMed]

104. Kim, D.H.; Jung, Y.J.; Lee, J.E.; Lee, A.S.; Kang, K.P.; Lee, S.; Park, S.K.; Han, M.K.; Lee, S.Y.; Ramkumar, K.M.; et al. SIRT1 Activation by Resveratrol Ameliorates Cisplatin-Induced Renal Injury through Deacetylation of P53. Am. J. Physiol.-Ren. Physiol. 2011, 301, F427-F435. [CrossRef]

105. Badary, O.A.; Abdel-Maksoud, S.; Ahmed, W.A.; Owieda, G.H. Naringenin Attenuates Cisplatin Nephrotoxicity in Rats. Life Sci. 2005, 76, 2125-2135. [CrossRef] 
106. Ramesh, G.; Reeves, W.B. Salicylate Reduces Cisplatin Nephrotoxicity by Inhibition of Tumor Necrosis Factor- $\alpha$. Kidney Int. 2004, 65, 490-498. [CrossRef]

107. McCully, J.D.; Cowan, D.B.; Pacak, C.A.; Toumpoulis, I.K.; Dayalan, H.; Levitsky, S. Injection of Isolated Mitochondria during Early Reperfusion for Cardioprotection. Am. J. Physiol.-Heart Circ. Physiol. 2009, 296, H94-H105. [CrossRef]

108. McCully, J.D.; Cowan, D.B.; Emani, S.M.; del Nido, P.J. Mitochondrial Transplantation: From Animal Models to Clinical Use in Humans. Mitochondrion 2017, 34, 127-134. [CrossRef] [PubMed]

109. Fu, A.; Shi, X.; Zhang, H.; Fu, B. Mitotherapy for Fatty Liver by Intravenous Administration of Exogenous Mitochondria in Male Mice. Front. Pharmacol. 2017, 8, 241. [CrossRef]

110. Cowan, D.B.; Yao, R.; Akurathi, V.; Snay, E.R.; Thedsanamoorthy, J.K.; Zurakowski, D.; Ericsson, M.; Friehs, I.; Wu, Y.; Levitsky, S.; et al. Intracoronary Delivery of Mitochondria to the Ischemic Heart for Cardioprotection. PLoS ONE 2016, 11, e0160889. [CrossRef] [PubMed]

111. Emani, S.M.; Piekarski, B.L.; Harrild, D.; del Nido, P.J.; McCully, J.D. Autologous Mitochondrial Transplantation for Dysfunction after Ischemia-Reperfusion Injury. J. Thorac. Cardiovasc. Surg. 2017, 154, 286-289. [CrossRef]

112. Ali Pour, P.; Kenney, M.C.; Kheradvar, A. Bioenergetics Consequences of Mitochondrial Transplantation in Cardiomyocytes. J. Am. Heart Assoc. 2020, 9, e014501. [CrossRef]

113. Court, A.C.; Le-Gatt, A.; Luz-Crawford, P.; Parra, E.; Aliaga-Tobar, V.; Bátiz, L.F.; Contreras, R.A.; Ortúzar, M.I.; Kurte, M.; Elizondo-Vega, R.; et al. Mitochondrial Transfer from MSCs to T Cells Induces Treg Differentiation and Restricts Inflammatory Response. EMBO Rep. 2020, 21, e48052. [CrossRef]

114. Torralba, D.; Baixauli, F.; Sánchez-Madrid, F. Mitochondria Know No Boundaries: Mechanisms and Functions of Intercellular Mitochondrial Transfer. Front. Cell Dev. Biol. 2016, 4, 107. [CrossRef] [PubMed]

115. Shi, X.; Zhao, M.; Fu, C.; Fu, A. Intravenous Administration of Mitochondria for Treating Experimental Parkinson's Disease. Mitochondrion 2017, 34, 91-100. [CrossRef]

116. Kitani, T.; Kami, D.; Matoba, S.; Gojo, S. Internalization of Isolated Functional Mitochondria: Involvement of Macropinocytosis. J. Cell. Mol. Med. 2014, 18, 1694-1703. [CrossRef] [PubMed]

117. Spees, J.L.; Olson, S.D.; Whitney, M.J.; Prockop, D.J. Mitochondrial Transfer between Cells Can Rescue Aerobic Respiration. Proc. Natl. Acad. Sci. USA 2006, 103, 1283-1288. [CrossRef] [PubMed]

118. Valenti, D.; Vacca, R.A.; Moro, L.; Atlante, A. Mitochondria Can Cross Cell Boundaries: An Overview of the Biological Relevance, Pathophysiological Implications and Therapeutic Perspectives of Intercellular Mitochondrial Transfer. Int. J. Mol. Sci. 2021, 22, 8312. [CrossRef] [PubMed]

119. Yip, H.-K.; Dubey, N.K.; Lin, K.-C.; Sung, P.-H.; Chiang, J.Y.; Chu, Y.-C.; Huang, C.-R.; Chen, Y.-L.; Deng, Y.-H.; Cheng, H.-C.; et al. Melatonin Rescues Cerebral Ischemic Events through Upregulated Tunneling Nanotube-Mediated Mitochondrial Transfer and Downregulated Mitochondrial Oxidative Stress in Rat Brain. Biomed. Pharmacother. 2021, 139, 111593. [CrossRef]

120. Pacak, C.A.; Preble, J.M.; Kondo, H.; Seibel, P.; Levitsky, S.; del Nido, P.J.; Cowan, D.B.; McCully, J.D. Actin-Dependent Mitochondrial Internalization in Cardiomyocytes: Evidence for Rescue of Mitochondrial Function. Biol. Open 2015, 4, 622-626. [CrossRef]

121. Levoux, J.; Prola, A.; Lafuste, P.; Gervais, M.; Chevallier, N.; Koumaiha, Z.; Kefi, K.; Braud, L.; Schmitt, A.; Yacia, A.; et al. Platelets Facilitate the Wound-Healing Capability of Mesenchymal Stem Cells by Mitochondrial Transfer and Metabolic Reprogramming. Cell Metab. 2021, 33, 283-299. [CrossRef]

122. Cowan, D.B.; Yao, R.; Thedsanamoorthy, J.K.; Zurakowski, D.; del Nido, P.J.; McCully, J.D. Transit and Integration of Extracellular Mitochondria in Human Heart Cells. Sci. Rep. 2017, 7, 17450. [CrossRef] [PubMed]

123. Preble, J.M.; Pacak, C.A.; Kondo, H.; MacKay, A.A.; Cowan, D.B.; McCully, J.D. Rapid Isolation and Purification of Mitochondria For Transplantation By Tissue Dissociation And Differential Filtration. J. Vis. Exp. 2014, 91, e51682. [CrossRef] [PubMed]

124. Maeda, H.; Kami, D.; Maeda, R.; Shikuma, A.; Gojo, S. Generation of Somatic Mitochondrial DNA-Replaced Cells for Mitochondrial Dysfunction Treatment. Sci. Rep. 2021, 11, 10897. [CrossRef]

125. Maeda, H.; Kami, D.; Maeda, R.; Murata, Y.; Jo, J.; Kitani, T.; Tabata, Y.; Matoba, S.; Gojo, S. TAT-dextran-Mediated Mitochondrial Transfer Enhances Recovery from Models of Reperfusion Injury in Cultured Cardiomyocytes. J. Cell. Mol. Med. 2020, 24, 5007-5020. [CrossRef] [PubMed]

126. Shin, B.; Saeed, M.Y.; Esch, J.J.; Guariento, A.; Blitzer, D.; Moskowitzova, K.; Ramirez-Barbieri, G.; Orfany, A.; Thedsanamoorthy, J.K.; Cowan, D.B.; et al. A Novel Biological Strategy for Myocardial Protection by Intracoronary Delivery of Mitochondria: Safety and Efficacy. JACC Basic Transl. Sci. 2019, 4, 871-888. [CrossRef]

127. Hwang, J.W.; Lee, M.J.; Chung, T.N.; Lee, H.A.R.; Lee, J.H.; Choi, S.Y.; Park, Y.J.; Kim, C.H.; Jin, I.; Kim, S.H.; et al. The Immune Modulatory Effects of Mitochondrial Transplantation on Cecal Slurry Model in Rat. Crit. Care 2021, 25, 20. [CrossRef]

128. Xu, Y.; Yu, Y.; Yang, B.; Hui, J.; Zhang, C.; Fang, H.; Bian, X.; Tao, M.; Lu, Y.; Shang, Z. Extracellular Mitochondrial Components and Effects on Cardiovascular Disease. DNA Cell Biol. 2021, 40,1-13. [CrossRef]

129. Masuzawa, A.; Black, K.M.; Pacak, C.A.; Ericsson, M.; Barnett, R.J.; Drumm, C.; Seth, P.; Bloch, D.B.; Levitsky, S.; Cowan, D.B.; et al. Transplantation of Autologously Derived Mitochondria Protects the Heart from Ischemia-Reperfusion Injury. Am. J. Physiol.-Heart Circ. Physiol. 2013, 304, H966-H982. [CrossRef]

130. Grazioli, S.; Pugin, J. Mitochondrial Damage-Associated Molecular Patterns: From Inflammatory Signaling to Human Diseases. Front. Immunol. 2018, 9, 832. [CrossRef] 
131. Kaza, A.K.; Wamala, I.; Friehs, I.; Kuebler, J.D.; Rathod, R.H.; Berra, I.; Ericsson, M.; Yao, R.; Thedsanamoorthy, J.K.; Zurakowski, D.; et al. Myocardial Rescue with Autologous Mitochondrial Transplantation in a Porcine Model of Ischemia/Reperfusion. J. Thorac. Cardiovasc. Surg. 2017, 153, 934-943. [CrossRef]

132. Moskowitzova, K.; Shin, B.; Liu, K.; Ramirez-Barbieri, G.; Guariento, A.; Blitzer, D.; Thedsanamoorthy, J.K.; Yao, R.; Snay, E.R.; Inkster, J.A.H.; et al. Mitochondrial Transplantation Prolongs Cold Ischemia Time in Murine Heart Transplantation. J. Heart Lung Transplant. 2019, 38, 92-99. [CrossRef]

133. Song, X.; Hu, W.; Yu, H.; Wang, H.; Zhao, Y.; Korngold, R.; Zhao, Y. Existence of Circulating Mitochondria in Human and Animal Peripheral Blood. Int. J. Mol. Sci. 2020, 21, 2122. [CrossRef] [PubMed]

134. Ulger, O.; Kubat, G.B.; Cicek, Z.; Celik, E.; Atalay, O.; Suvay, S.; Ozler, M. The Effects of Mitochondrial Transplantation in Acetaminophen-Induced Liver Toxicity in Rats. Life Sci. 2021, 279, 119669. [CrossRef] [PubMed]

135. Kubat, G.B.; Ozler, M.; Ulger, O.; Ekinci, O.; Atalay, O.; Celik, E.; Safali, M.; Budak, M.T. The Effects of Mesenchymal Stem Cell Mitochondrial Transplantation on Doxorubicin-mediated Nephrotoxicity in Rats. J. Biochem. Mol. Toxicol. 2021, 35 , e22612. [CrossRef]

136. Zhang, Y.; Yu, Z.; Jiang, D.; Liang, X.; Liao, S.; Zhang, Z.; Yue, W.; Li, X.; Chiu, S.-M.; Chai, Y.-H.; et al. IPSC-MSCs with High Intrinsic MIRO1 and Sensitivity to TNF- $\alpha$ Yield Efficacious Mitochondrial Transfer to Rescue Anthracycline-Induced Cardiomyopathy. Stem Cell Rep. 2016, 7, 749-763. [CrossRef] [PubMed]

137. Kim, M.J. Delivery of Exogenous Mitochondria via Centrifugation Enhances Cellular Metabolic Function. Sci. Rep. 2018, 13, 3330. [CrossRef]

138. Nakamura, Y.; Park, J.-H.; Hayakawa, K. Therapeutic Use of Extracellular Mitochondria in CNS Injury and Disease. Exp. Neurol. 2020, 324, 113114. [CrossRef] [PubMed]

139. Cozzolino, M.; Marin, D.; Sisti, G. New Frontiers in IVF: MtDNA and Autologous Germline Mitochondrial Energy Transfer. Reprod. Biol. Endocrinol. 2019, 17, 55. [CrossRef]

140. Chen, K.; Lu, P.; Beeraka, N.M.; Sukocheva, O.A.; Madhunapantula, S.V.; Liu, J.; Sinelnikov, M.Y.; Nikolenko, V.N.; Bulygin, K.V.; Mikhaleva, L.M.; et al. Mitochondrial Mutations and Mitoepigenetics: Focus on Regulation of Oxidative Stress-Induced Responses in Breast Cancers. Semin. Cancer Biol. 2020. [CrossRef]

141. Park, A.; Oh, M.; Lee, S.J.; Oh, K.-J.; Lee, E.-W.; Lee, S.C.; Bae, K.-H.; Han, B.S.; Kim, W.K. Mitochondrial Transplantation as a Novel Therapeutic Strategy for Mitochondrial Diseases. Int. J. Mol. Sci. 2021, 22, 4793. [CrossRef]

142. Hersant, B.; Sid-Ahmed, M.; Braud, L.; Jourdan, M.; Baba-Amer, Y.; Meningaud, J.-P.; Rodriguez, A.-M. Platelet-Rich Plasma Improves the Wound Healing Potential of Mesenchymal Stem Cells through Paracrine and Metabolism Alterations. Stem Cells Int. 2019, 2019, 1234263. [CrossRef]

143. Wu, H.-C.; Fan, X.; Hu, C.-H.; Chao, Y.-C.; Liu, C.-S.; Chang, J.-C.; Sen, Y. Comparison of Mitochondrial Transplantation by Using a Stamp-Type Multineedle Injector and Platelet-Rich Plasma Therapy for Hair Aging in Naturally Aging Mice. Biomed. Pharmacother. 2020, 130, 110520. [CrossRef]

144. Weissig, V.; Boddapati, S.V.; Cheng, S.-M.; D'souza, G.G.M. Liposomes and Liposome-like Vesicles for Drug and DNA Delivery to Mitochondria. J. Liposome Res. 2006, 16, 249-264. [CrossRef] [PubMed]

145. Chang, J.-C.; Hoel, F.; Liu, K.-H.; Wei, Y.-H.; Cheng, F.-C.; Kuo, S.-J.; Tronstad, K.J.; Liu, C.-S. Peptide-Mediated Delivery of Donor Mitochondria Improves Mitochondrial Function and Cell Viability in Human Cybrid Cells with the MELAS A3243G Mutation. Sci. Rep. 2017, 7, 10710. [CrossRef] [PubMed]

146. Marlein, C.R.; Zaitseva, L.; Piddock, R.E.; Robinson, S.D.; Edwards, D.R.; Shafat, M.S.; Zhou, Z.; Lawes, M.; Bowles, K.M.; Rushworth, S.A. NADPH Oxidase-2 Derived Superoxide Drives Mitochondrial Transfer from Bone Marrow Stromal Cells to Leukemic Blasts. Blood 2017, 130, 1649-1660. [CrossRef] [PubMed]

147. Sahinbegovic, H.; Jelinek, T.; Hrdinka, M.; Bago, J.R.; Turi, M.; Sevcikova, T.; Kurtovic-Kozaric, A.; Hajek, R.; Simicek, M. Intercellular Mitochondrial Transfer in the Tumor Microenvironment. Cancers 2020, 12, 1787. [CrossRef]

148. Dong, L.-F.; Kovarova, J.; Bajzikova, M.; Bezawork-Geleta, A.; Svec, D.; Endaya, B.; Sachaphibulkij, K.; Coelho, A.R.; Sebkova, N.; Ruzickova, A.; et al. Horizontal Transfer of Whole Mitochondria Restores Tumorigenic Potential in Mitochondrial DNA-Deficient Cancer Cells. eLife 2017, 6, e22187. [CrossRef]

149. Elliott, R.L.; Jiang, X.P.; Head, J.F. Mitochondria Organelle Transplantation: Introduction of Normal Epithelial Mitochondria into Human Cancer Cells Inhibits Proliferation and Increases Drug Sensitivity. Breast Cancer Res. Treat. 2012, 136, 347-354. [CrossRef]

150. Caicedo, A.; Fritz, V.; Brondello, J.-M.; Ayala, M.; Dennemont, I.; Abdellaoui, N.; de Fraipont, F.; Moisan, A.; Prouteau, C.A.; Boukhaddaoui, H.; et al. MitoCeption as a New Tool to Assess the Effects of Mesenchymal Stem/Stromal Cell Mitochondria on Cancer Cell Metabolism and Function. Sci. Rep. 2015, 5, 9073. [CrossRef]

151. Lohlamoh, W.; Soontornworajit, B.; Rotkrua, P. Anti-Proliferative Effect of Doxorubicin-Loaded AS1411 Aptamer on Colorectal Cancer Cell. Asian Pac. J. Cancer Prev. 2021, 22, 2209-2219. [CrossRef] [PubMed] 